-ISSN: 2148-0494

dergÍabant (AİBÜ İlahiyat Fakültesi Dergisi), Güz 2020, Cilt:8, Sayı:2, 8:588-612

Geliş Tarihi: 29.07.2020 Kabul Tarihi: 23.10.2020

Araștırma Makalesi

Doi: https://doi.org/10.33931/abuifd.775576

\title{
Süleyman Hasbî’nin “Kitâb-ı Mirkāt-i Merâtib-i İlm-i Ledünnî fî Menâkıb-i Abdülkādir-i Geylânî” Adlı Menâkıbnâmesindeki Bazı Tasavvufî \\ Kavramlar
}

Cüveyriye İltuş*

Öz

Menâkıbnâmeler, kaleme alındığı dönem itibarıyla içinde bulunulan kültürel ve sosyal çevre hakkında tarihî bilgiler barındırması yönüyle oldukça zengin içeriğe sahip dokümanlardır. Özellikle tasavvuf ilminin ilgi sahasına girmesi yönüyle sûfî menâkıbnâmelerinde de konu edinilen sûfînin hayatı, gönül dünyası, tasavvufî tecrübesi hakkında mühim bilgiler bulunmaktadır. Sahip olunan tasavvufî tecrübenin anlaşılmasında tasavvufa dair kavramların ele alınış şeklini ve mana çerçevesini analiz etmek önem arz etmektedir. Bu açıdan bakıldığı takdirde menâkıbnâmeler önemli veri kaynağı durumundadır. Tasavvuf tarihinde önemli iz bırakmış sûfîler hakkında nakledilen menkabelerin çok olması, söz konusu sufilerin yaşadıkları döneme bıraktığı etki sebebiyledir. Kādiriyye tarikatının kendisine nispet edildiği Abdülkādir-i Geylânî (ö. 561/1165-66) de tasavvuf tarihinde etkin bir role sahip olması sebebiyle hakkında birçok menkabe nakledilen bir sûfîdir. Bu makalede, Süleyman Hasbî’ye (ö. 1909) ait olan ve Abdülkâdir-i Geylânı̂’nin hayatı hakkındaki menkabeleri, onun tasavvufa dair görüşlerini içeren 'Kitâb-ı Mirkāt-i Merâtib-i İlm-i Ledünnî fî Menâkıb-i Abdülkādir-i Geylânî isimli menâkıbnâmede yer alan ve Abdülkâdir-i Geylânî'nin gönül dünyasını yansıtan kavram ve konuların, zikri geçen menâkıbnâme özelinde izdüşümü ele alınmıştır.

Anahtar Kelimeler: Tasavvuf, Menâkıbnâme, Sûfî, Tasavvufî Kavramlar, Abdülkādiri Geylânî.

\section{Some Sufistic Concepts in Sulayman Ḥasbī’s Menāḳib-nāme, "Kitab-i Mirkāt-i Marātib-i Ilm-i Ladunnī fĩ Menāḳib-i 'Abd al-Qādir al-Jīlānī”}

\begin{abstract}
Menāḳib-nāmes provide data to many areas as they give important historical information about the cultural and social environment. Especially sufistic menākibnāmes, which are subjects of interest for Sufism, provide important information about the mentioned sufist in terms of his/her life, emotions, and sufistic experiences. In understanding the sufistic experiences, it is important to examine how and to what
\end{abstract}


extent concepts related to Sufism are handled. From this point of view, menākibnāmes are important sources of data. The reason for the abundance of anecdotes conveyed about sufists who made a mark in the history of Sufism is their influence. 'Abd al-Qādir al-Jīlānī (d. 561/1165-66), to whom the establishment of the Kădiriyya sect is attributed, is an important sufist about whom many anecdotes were conveyed because of his influential role in the history of Sufism. In this article, the concepts and issues that reflect the emotions of 'Abd al-Qādir al-Jīānī in the menākibibāme named Kitab-i Mirkāt-i Marātib-i Ilm-i Ladunnī fì Menāḳib-i 'Abd al-Qādir al-Jīlānī which was written by Sulayman Hasbī (d. 1909) and which presented the anecdotes of 'Abd alQādir al-Jīlānī and his ideas on Sufism, were examined within the context of this menākib-nāme.

Keywords: Sufism, Menāḳib-nāme, Șūfì, Mystic Concepts, 'Abd al-Qādir al-Jīlānī.

\section{Giriş}

Tefekkür dünyasının zenginliği ve birikimi, bir medeniyeti oluşturan ve varlığını devam ettirmesini sağlayan unsurlardandır. Bu unsur kendini farklı şekillerde izhar ederek toplumsal hafızayı oluşturmuştur. Menâkıbnâmeler de toplumsal hafızanın aktarımını ve devamılığını sağlayan dokümanlardır. Gerek konu edinilen şahsiyetler gerek dönemin sosyal ve kültürel özelliğiyle ilgili birçok bilgi ihtiva etmesi sebebiyle menâkıbnâmeler farklı alanlara katkı sağlamaktadırlar. Sûfî menâkıbnâmelerinde de konu edinilen şahsiyetlerin hayatı, tasavvufî görüşleri, döneminin tasavvuf anlayışı gibi konular hakkında bilgiler bulunmaktadır.

Kur'an'da düşünme ve idrak merkezi ${ }^{1}$ olarak nitelendirilen kalp, tasavvufun erbabı olan sûfiler açısından, Hakk'ın nazargâhı ve tecelligâhı olarak görülmesi sebebiyle merkezî öneme sahiptir. $\mathrm{Bu}$ nedenle kalp tasfiyesi tasavvufun hedeflerinden biridir. Tasavvufta kalp, imanın, keşf ve ilhamın aynı zamanda duyguların merkezi konumundadır. Bu kalbî duygu ve düşüncelerin dile aktarılmasıyla tasavvufî kavram ve ıstılahlar oluşmuştur. Bu kavramların genel kabul gören anlamlarıyla birlikte her sûfînin kendi gönül âleminde kazandığı yeni anlam mertebeleri mevcuttur. Menâkıbnâmeler özelinde de kavram ve konuların bu anlam mertebelerini keşfetmek ve diğer kavramlarla ilişkisini ortaya koymak tefekkür dünyasına katkı sağlayacaktır.

$\mathrm{Bu}$ amaçla makalede, tasavvuf tarihine önemli bir iz bırakmış olan Abdülkādir-i Geylânî’nin (ö. 561/1165-66) menkabelerinden bahseden ve Pirevişteli Süleyman Hasbî Efendi'ye (ö. 1327/1909) ait olan Kitâb-ı Mirkāt-i Merâtib-i İlm-i Ledünnî fî Menâkıb-i Abdülkādir-i Geylânî isimli menâkıbnâme üzerinde çalıșılmıştır. Bu menâkıbnâme, Abdülkādir-i Geylânî'nin hayatından bahsetmekle birlikte tasavvufî kavram ve konularla ilgili yaptığı izahlar açısından da önemlidir. 0, sohbetleri esnasinda veya kendisine sorulan sorular üzerine tasavvufî kavram ve konularla ilgili olmak üzere gönül dünyasını yansıtan açıklamalarda bulunmuştur. Eserde bazı kavramlarla ilgili açıklamalar ardı ardına daha düzenli bir şekilde yer almakla birlikte, mana itibariyle daha geniş olan konuların (tevekkül, sıdk, muhabbet vb.) izahına yönelik açıklamalar menâkıbnâmenin farklı yerlerindeki açılamalarla

Muhammed 47/24; Kâf 50/37. 
mezcedilmiştir. Bu çalışmada, Süleyman Hasbî Efendi'nin hayatı hakkında bilgi verildikten sonra menâkıbnâmede yer alan kavram ve konular, "Tahalluka Dair Kavramlar" ve "Tahakkuka Dair Kavramlar" olmak üzere iki ana başlık altında ele alınmıștır. Kavramlar hakkında kısaca tanıtıcı bilgiler verildikten sonra ise Abdülkādir-i Geylânî'nin konuyla ilgili görüşlerine yer verilmiştir.

\section{Pirevişteli Süleyman Hasbî Efendi'nin (ö. 1327/1909) Hayatı ve "Kitâb-ı Mirkāt-i Merâtib-i İlm-i Ledünnî fî Menâkıb-i Abdülkādir-i Geylânî” Adlı Eseri}

Süleyman Hasbî Efendi, Dırama sancağına bağlı Pirevişteli olup ilim ve mârifet sahibi bir zat olduğu kaynaklarda belirtilir. Bir müddet şer'î hâkimlikle vazife görmüştür. Sonradan saray kâtipleri arasına girmiş ve arkasından baş kâtip olmuştur. 1327 h. De vefât edip Edirnekapısı haricinde İbrahim Halebî'nin kabri civarında defnedilmiştir. Matbu eserleri şunlardır:

(Tafsil-i Kavaidi Külliye Şerhi), (Terceme-i Tâtîri'l-Enami fi Tabiri'l-Menami li'n-Nablusi), (Terceme-i Gunyeti't-Talibîn li'ş-Şeyh Hazret-i Abdulkâdir Geylânî, elMüsemma bi umdeti's-Salihîn), (Kitâb-ı Mirkāt-i Merâtib-i İlm-i Ledünnî fi Menâkıb-i Abdülkādir Geylânî), (Şerh ve Terceme-yi Delâil-i Abdülkādir Geylânî), (Risâletü'littihâdiyye li saadeti'l-milleti'l-İslâmiye). Gelenbevîzade Ahmed Tevfik Efendi'nin tercemeye başladığı (Tahafütü'l-felâsife)'yi de tamamlamıştır. ${ }^{2}$

Yukarıda verilen bilgilerden anlaşılacağı üzere Süleyman Hasbî Efendi ilmî birikimi sayesinde sarayda baş kâtip olarak vazife görmüştür. 0 , bu birikimiyle Abdülkādir-i Geylânî'nin ve Gazzâlînnin bazı eserlerini Türkçeye kazandırmıştır. Abdülkādir-i Geylânî'den bahseden Türkçe iki menâkıbnâme vardır. Bunlar İsmail Kemâl el-Ümmî el-Karamânî̀ye (ö. 880/1475?) ait olan Menâkıb-i Hazret-i Abdülkādir ve çalışmaya konu olan Süleyman Hasbî Efendi'nin Kitâb-ı Mirkāt-i Merâtib-i İlm-i Ledünnî fì Menâkıb-i Abdülkādir-i Geylânî̉dir. Osmanlıca yazılmış bu eser üzerinde çalışma yapılarak eseri günümüze kazandırmak ve menâkıbnamelerde yer alan kavramların geçirdiği değişimi görmek üzere yapılacak uzun soluklu çalışmalara katkıda bulunmak amaçlanmıştır.

Bu makalede çalışmaya konu olan Kitâb-ı Mirkāt-i Merâtib-i İlm-i Ledünnî fî Menâkıb-i Abdülkādir-i Geylânî isimli eser 1300/1883 tarihinde, Pirevişteli Süleyman Hasbî tarafından yazılmıștır. 312 sayfadan ibaret olup, ${ }^{3}$ basımı yapılmıștır. Eser, "Süleyman Hasbî, Kitâb-ı Mirkāt-i Merâtib-i İlm-i Ledünnî fî Menâkıb-i Abdülkādir-i Geylânî (İstanbul: M.Ü. İlahiyat Fakültesi Kütüphanesi, Öğüt, 23418); (İstanbul: İstanbul Büyükşehir Belediyesi Atatürk Kitaplığı, Osman Ergin, 2558)”de de bulunmaktadır. Müellifin beyan ettiği üzere eser, Abdülkādir-i Geylânînnin bazı hâlleri, doğumu, kerâmetleri, mücâhedesi, ilmi, fazileti; şeyhleri, mürîdleri, tasavvufî

2 Bursalı Mehmed Tâhir, Osmanlı Müellifleri, haz. Ali Fikri Yavuz - İsmail Özen (İstanbul: Meral Yayınevi, 1972-1975), 1/335-336.

Dilaver Gürer, Abdülkādir-i Geylânî Hayatı, Eserleri ve Görüşleri (İstanbul: İnsan Yayınları, 2009), 134. 
görüşleri ve hakikat erbablarının beyanlarından bir kısmı; meşâyih ve ârifînin Abdülkādir-i Geylânî hakkındaki methiyeleri gibi bölümlerden oluşmaktadır. ${ }^{4}$

\section{Tahalluka Dair Kavramlar}

Tasavvufun "tahalluk" ve "tahakkuk" olmak üzere iki mertebesi yani iki boyutu vardır. "Tahalluk", tasavvufun eğitim boyutudur. Tasavvufi hayat, tarîkat, manevî makamlar, seyr ü sülûk ve âdâb gibi konuları kapsar. ${ }^{5}$

Makalenin bu bölümünde, mezkûr menâkıbnâmede yer alan "Tahalluka Dair Kavramlar" hakkındaki Abdülkādir-i Geylânî’nin görüş ve açıklamalarına yer verilmiştir. İlk önce her bir kavramla ilgili kısaca bilgiler verilmiş olup daha sonra ise Abdülkādir-i Geylânî’nin kavram ve konuyu nasıl ele aldığı üzerinde durulmuştur.

\section{1. İbadet ve Ahlâka Dair Kavramlar}

\subsubsection{Güzel Ahlâk}

"Mekârim-i ahlâk", "ahlâk-ı hasene" ve "ahlâk-ı hamîde" olarak da isimlendirilen "güzel ahlâk", öfkeye hâkim olma, sabır, af, yardım etme, doğruluk, hayâ, tevâzu, Allah'tan sakınma, Allah ve insanlar hakkında hüsn-i zan'da bulunma, hayırlı işlere öncülük etme, adalet, sâlihlere muhabbet besleme gibi Allah ve Rasûlü açısından güzel görülen sıfatlardır. ${ }^{6}$

Abdülkādir-i Geylânîyye göre güzel ahlâk, Cenâb-ı Hakk'ı bildikten sonra halkın cefasından dolayı kalbin ve zihnin kederli olmaması; halkın cefasının hiçbir etkisinin bulunmamasıdır. 0, güzel ahlâkı ayrıca, nefsin zelîl ve hakîr bilinmesi ve nefisten gelen mârifetin cüz'î ve ehemmiyetsiz tutulması olarak da niteleyerek nefisle irtibatına da dikkat çekmiştir. "Yaratanların en güzeli olan Allah'ın şânı ne yücedir"7 hükmünce ve "Sen kitap nedir, iman nedir bilmezdin"8 âyetlerinde beyan edildiği üzere insana ihsan olunan imanın yüceliğini idrak etmek de güzel ahlâktır. Tasavvuf anlayışına göre Müslümanlar avam, havâs olmak üzere temelde iki kısma ayrılır. Abdülkādir-i Geylânî'ye göre havâsta zâhir olan ubûdiyetin, ubûdiyetle ilgili övülecek özelliklerin, fâziletlerin efdali ise güzel ahlâktır. ${ }^{9}$

Abdülkādir-i Geylânî'nin açıklamaları değerlendirildiğinde güzel ahlâkın mârifetullah, nefis, ubûdiyet ve imanla ilişkisi çerçevesinde geniş manada ele alındığı görülmektedir. Ayrıca güzel ahlak-iman ilişkisinin âyetler üzerinden izahı da söz konusudur.

Süleyman Hasbî, Kitâb-ı Mirkāt-i Merâtib-i İlm-i Ledünnî fî Menâkıb-i Abdülkādir-i Geylânî (İstanbul: Matbaa-i Osmaniye, 1300/1883), 3-4.

5 Hasan Kâmil Yılmaz, "Tasavvufla İlgili Sorular ve Cevaplar" (el-Luma', İslâm Tasavvufu içerisinde), (İstanbul: Altınoluk Yayınları, 1996), 444.

6 Mansûr Alî Nâsıf el- Hüseynî, et-Tâcu'l-câmiu' li'l-usûl fî ehâdîsi'r-resûl (İstanbul: Mektebetü Pamuk, 1962), 5/47.

7 Kur'ân-ı Kerîm Meâli, çev. Halil Altuntaş - Muzaffer Şahin (Ankara: Diyanet İşleri Başkanlığı Yayınları, 2009), el-Mü'minûn 23/14.

eş-Şûrâ 42/52.

Hasbî, Kitâb-ı Mirkāt-i Merâtib-i İlm-i Ledünnî fî Menâkıb-i Abdülkādir-i Geylânî, 130-131. 


\subsubsection{Tevbe ve İnâbe}

Tevbe, kelime olarak "günahtan dönmek, rücû etmek, dönüş yapmak, pişmanlık duymak" gibi anlamlara gelir.10 İnâbe ise "bir şeyin tekrar geri dönmesi, dönmek, tâata dönmek ve vekil yapmak" gibi anlamlara gelir. ${ }^{11}$ Tasavvufta ise tevbe kavramının üç derecede yahut üç makam halinde ele alındığı görülmektedir. Nitekim azap korkusundan dolayı tevbe eden kimse tevbe ehli; sevap ümidiyle tevbe edene inâbe ehli; azap korkusu veya sevap ümidi olmayıp sadece emri yerine getirmek için tevbe eden kimse ise evbe ehli olarak mütalaa edilmektedir. ${ }^{12}$

Abdülkādir-i Geylânî tevbeyi, Allah Teâlâ Hazretleri'nin inâyet nazarı, ilham ve işaretiyle kulunu kendine çekmesi ve feyizlendirmesi; şefkat ve merhametinin yüceliğiyle de mâsivâ ve dünya ile olan alâkayı kulunun kalbinden çıkarması olarak nitelendirir. Hakk'ın nazarı neticesinde, kulun kalbinin yanlış olan her şeyden geri dönerek doğru olana ve Cenâb-ı Hakk'a yönelmesi tevbeyi meydana getirir. Bu cezbedilmede, ruh kalbe tâbi olur ve akıl ruha uyar. Bu durumda tevbe onlara refakat eder. Böylece "İşin tamamı Allah'a aittir"13 yüce emrince benzersiz sırlar zâhir olur. ${ }^{14}$ $\mathrm{Bu}$ cümlelerden anlaşıldığı üzere Abdülkādir-i Geylânî tevbenin nasıl meydana geldiğini ifade ederek tevbenin kalbî yönüne dikkat çekmiş ve dilin tevbesinden ziyade kalbin tevbesine vurgu yapmıştır.

Abdülkādir-i Geylânî, tevbenin izahından sonra tevbeyle bağlantılı ikinci menzil olan inâbeyi açılklamıştır. Ona göre inâbe ise Cenâb-ı Hakk'ın "Rabbiniz'e dönün"15 yüce emri hükmünce salikin Allah'tan başka her şeyden yüzünü çevirerek tam bir teveccühle, mükâşefe ve hakikat erbabının nezdinde, Allah'a vusûle ulaşana kadar yüksek makamları talep etmesi, derece ve makamlarında duraklamaktan kaçınması ve ayrıca sırların zirvesine, yüksek mertebeye terakkiye azmetmesidir. 16 Ayrıca inâbe, kurbet derecelerine ve vuslata nâil olmak, bu huzur ve muhâdaradan sonra ise bunların küllisinden Hakk'a rücu etmek, fenâfillaha erişmektir. İnâbe, salikin Allah Teâlâ hazretlerinin kahr ve celâlinden korkması ve çekinmesi ile lütuf ve cemâline; gazabından rızâ-yı ilâhiyesine dönmesidir. Hem Allah'a rağbet etmek hem de mâsivâya bağlılıktan korku neticesinde salikin Allah'a yönelmesi, "Şu halde Allah'a sığının"17 âyetinde belirtildiği gibi ilâhî yöne doğru seyr ü sefer etmesi ve makam-ı fenâya kadem basmasıdır. ${ }^{18}$ Abdülkādir-i Geylânî, inâbenin gerçekleşmesinde

Bk. İbn Manzûr Ebu'l-Fadl Cemâluddin Muhammed b. Mükrim b. Ali el-Ensârî, Lisânü'l-Arab, (Kahire: Dârü'l-Meârif, 1979), 5/454.

Ebû Abdurrahman Halil b. Ahmed, Kitâbü'l-Ayn, thk. A. Hindâvî (Beyrut: Dâru'l-Kütübi'l-İlmiyye, 2003), 4/275; Ebü’l-Kāsım Hüseyn b. Muhammed b. el-Mufaddal er-Râgıb el-İsfahânî, el-Müfredât (Dımeșk: Daru'l-Kalem, 2000), 508.

Ebü'l-Hasen Alî b. Osmân b. Ebî Alî el-Cüllâbî el-Hücvîrî, Keş̧ü'l-mahcûb (Hakikat Bilgisi), Haz. Süleyman Uludağ (İstanbul: Dergâh Yayınları, 2010), 357.

Âl-i İmrân 3/154.

Hasbî, Kitâb-ı Mirkāt-i Merâtib-i İlm-i Ledünnî fî Menâkıb-i Abdülkādir-i Geylânî, 123.

ez-Zümer 39/54.

Hasbî, Kitâb-ı Mirkāt-i Merâtib-i İlm-i Ledünnî fì Menâkıb-i Abdülkādir-i Geylânî, 121-122.

ez-Zâriyât 51/50.

Hasbî, Kitâb-ı Mirkāt-i Merâtib-i İlm-i Ledünnî fî Menâkıb-i Abdülkādir-i Geylânî, 123. 
mürşid-i kâmilin yerine değinmiş ve inâbe konusunu kurb ve fenâfillah kavramlarıyla bağlantılı olarak izah etmiștir.

\subsubsection{Zikir}

Zikir, hafızada tutmak, hatırlamak, diliyle söylemek ${ }^{19}$ demektir. Tasavvufî anlamda zikir Allah'ı anmak ve hatırlamak, O'nu unutmamak ve gaflet halinde olmamaktır. ${ }^{20}$ Sûfîlere göre zikirden maksat Allah'ın zâtı, sıfatları, isimleri, ihsanının bolluğu, takdirinin geçerliliği gibi hususlarda kalbin uyanıklığını sağlamak ${ }^{21}$ Allah'ı kalpte hazır tutmak ve O'nu görüyormuş gibi murakâbe etmektir ki bu "ihsan" makamıdır. Halis bir zikir için öncelikle takvânın gerçekleşmesi gerekir. Gerçek takvâ ise haramlardan kaçınmak ve faydasız, gereksiz şeylerden uzaklaşmakla elde edilir. ${ }^{22}$

Abdülkādir-i Geylânî, tasavvufî öneme sahip olan zikir konusuyla ilgili olarak şunları ifade etmiştir: "İbadetleriniz arza dahil olmaz ancak semâya yükselir. Allah Teâlâ "Güzel sözler ona yükselir; sâlih ameli de güzel sözler yükseltir"23 diye buyurmuştur. Bu âyetteki "güzel sözler", kelime-i şehâdet, tâat, ibadet ve zikrullahtır. Onları Allah Teâlâ'nın dergâh-ı kabulüne yükselten ise amel-i sâlihtir. Amel-i sâlih olmayınca o güzel sözler ve ibadetler, makbul ve faydalı değildir."24 Ona göre zikrin makbul olmasının temel şartı, sâlih amel olarak kişinin davranışlarına yansımasıdır. $\mathrm{Bu}$ durum, bâtındaki güzelliklerin zâhire aksettirilmesinin önemi olarak da nitelendirilebilir.

Abdülkādir-i Geylânî, "Artık siz beni anın ki ben de sizi anayım"25 âyeti hükmünce zâkir ve mezkûr olunmadığı takdirde kişinin gaflette olacağını belirtir. Böyle bir kişinin ise varlığıyla yokluğu birbirine eşittir. Zikirden gafil olan kişi, mütekaddimînin makamlarına vusûlden de uzaktır. Çünkü mütekaddimîn "Onlar ayakta dururken, otururken, yatarken hep Allah'ı anarlar"26 hükmüne göre hareket ederlerdi. Kıyam etseler zikrullah ile kıyam ederler, otursalar zikrullah ile otururlardı. Uyusalar ve uyansalar zikrullah ile uyur ve uyanırlardı. Hâsılı, zikir onların lisanlarından eksik olmazdı. Onlara âfet ve bela isabet ettiğinde rızâ ile kabul ederler, Allah'tan görüp halktan görmezlerdi ve bir sebep de zikretmezlerdi. Eğer zikredecek olsalardı 'bu âfet ve belâ, günah ve kusurumuz sebebiyle bize isabet etmiștir' derlerdi.27 Abdülkādir-i Geylânî bu açlklamalarında zikrin sürekliliğine dikkat çekmiştir. Zira zikrin kalbe kâmil manada yerleşmesinin yolu, devamlı olmasından geçmektedir. 0 ayrıca zikir-rızâ ilişkisini de ifade etmiştir.

\footnotetext{
İbn Manzûr, Lisânü'l-Arab, 3/1507.

Süleyman Uludağ, Tasavvuf Terimleri Sözlüğü (İstanbul: Kabalcı Yayıncılık, 2012),393.

Ebû Nasr Abdullah b. Alî b. Muhammed es-Serrâc et-Tûsî, el-Lüma'fî târîhi't-tasavvufi'l-İslâmî, nşr. Abdülhalîm Mahmud - Tâhâ Abdülkâdir Server (Kahire: y.y., 1960), 291.

Ebû Hafs Şihâbüddîn Ömer b. Muhammed b. Abdillâh b. Ammûye el-Kureşî el-Bekrî esSühreverdî, Avârifü'l-maârif (Mısır: Mektebetü'l-Allâmiyye, 1358/1939), 221-222.

Fâtır 35/10.

Hasbî, Kitâb-ı Mirkāt-i Merâtib-i İlm-i Ledünnî fì Menâkıb-i Abdülkādir-i Geylânî, 169-170.

el-Bakara 2/152.

Âl-i İmrân 3/191.

Hasbî, Kitâb-ı Mirkāt-i Merâtib-i İlm-i Ledünnî fî Menâkıb-i Abdülkādir-i Geylânî, 160.
} 
Abdülkādir-i Geylânî ayrıca zikrin dereceleri ve etkilerinden de bahsetmiştir. Onun belirttiğine göre zikrin en yüksek derecesi Cenâb-ı Hakk'ın inâyetiyle, Hak'tan bir işaretle zâkir olan salikin fuâdında meydana gelen tesir ve teessürdür. Salikin gönlünü yakıp yandıran zikir, daimî zikirdir. Bu vasıftaki zikirde nisyan, zâkiri zikirden menetmez ve gaflet zâkirin kalbinde bulunan safvete keder, bulanıklık getiremez. "Ey iman edenler! Allah'ı çokça zikredin"28 âyetinde belirtilen zikr-i kesîr bu zikirdir ve âyette Allah Teâlâ bütün mü'minlere her iş ve imkânda zikir, tehlîl, tahmîd ve tekbiri emretmiştir. Zikrin en güzeli ise Allah Teâlâ tarafından vârid olarak mahal-i esrârda sabit olan hatırlatmaların, salik ve zâkiri heyecanlandırmasıyla meydana gelen zikirdir. ${ }^{29}$

İslâm dininin üç temel sacayağı vardır ve bu üçü birbirini tamamlamadığı müddetçe eksiklik ortaya çıkar. Bunlar iman, ibadet ve ahlâktır. Eğer bir gaz lambası tasavvur edilecek olunursa, o lambanın fitilinin yanması iman; o ateşin sönmesini ya da azalmasını engelleyen cam fanus ibadet ve o lambanın güçlü şekilde aydınlatması ise ahlâktır. Zikrullah ise bu lambanın yağıdır ve onların güçlenmesini sağlar. Abdülkādir-i Geylânî tasavvufun merkezî öneme sahip konularından olan zikir kavramını hem genel manada hem de seyr-ü sülûk çerçevesinde ele alarak önemi ve etkisini açıklamıştır. 0 böylece zikir-kalp arasındaki güçlü bağı da izah etmiştir.

\subsubsection{Dua ve Dereceleri}

Dua kelimesi sözlükte "çağırmak, nidâ, seslenmek, davet etmek, istemek, yardım talep etmek ve rağbet etmek" gibi anlamlara gelmekte olup ${ }^{30}$ tasavvufta dua ise kulun Hakk'a yakarışıdır. Halkın duası lisanla, zâhitlerinki fiille, âriflerinki hal diliyledir. ${ }^{31}$

Abdülkādir-i Geylânî dua hakkında kendisine sorulan soru üzerine duanın derecelerinden bahsetmiş, âyetlerle örneklendirmek suretiyle konuyu izah etmiştir. Ona göre duanın derecesi üçtür. Bunlar; duayı tasrîh, ta'rîz ve işarettir. Duayı tasrîh, olması talep edilen ve gerçekleşmesi istenen hususun ismini açıklayarak telaffuz etmektir. Ta'rîz, dua içinde veya söz içinde gizlidir. İşaret, fiil içinde gizli bulunan duadır. Hz. Peygamber'in (s.a.s.) “Allah’ım bizi göz açıp kapayıncaya kadar olsa dahi nefsimizle baş başa bırakma” 32 hadis-i şerîfi ta'rîz derecesinde olan duadandır. Hz. Peygamber (s.a.s.) bu duada ümmetini murad etmiştir. Hz. İbrahim’in “Ey Rabbim! Ölüyü nasıl diriltiyorsun bana göster" 33 kavl-i şerîfi işaret yoluyla olan duadır ve onda

el-Ahzâb 33/41.

Hasbî, Kitâb-ı Mirkāt-i Merâtib-i İlm-i Ledünnî fî Menâkıb-i Abdülkādir-i Geylânî, 119.

Râgıb el-İ̀sfahânî, el-Müfredât, 315; İbn Manzûr, Lisânü'l-Arab, 16/1385.

Uludağ, Tasavvuf Terimleri Sözlüğ̈̈, 111.

Ebû Dâvûd Süleymân b. el-Eş'as b. İshâk es-Sicistânî el-Ezdî, "Sünen-i Ebû Dâvûd", el-Kütübü'sSitte, (Mevsûatü'l-Hadîs eș-Șerîf içerisinde), haz. Sâlih b. Abdulazîz (Arabistan: Dâru's-Selâm, 1421/2000), “Edeb”, 318 ( No: 5090). 
rü'yete işâret olunmuştur. Hz. Musa'nın "Rabbim! Bana (kendini) göster; seni göreyim" ${ }^{34}$ kavl-i şerîfi tasrîh yoluyla olan duadır ve onda nazar tasrîh edilmiştir. ${ }^{35}$

Abdülkādir-i Geylânînnin bu açıklamalarında duanın derecelerinden bahsettiği ve her bir dereceyi de Hz. Muhammed, Hz. İbrahim ve Hz. Musâ'nın dualarından bahseden hadis ve âyetlerle örneklendirerek izah ettiği görülmektedir.

\subsubsection{Takvâ}

Takvâ, "korumak, korunmak, sakınmak, saygı göstermek, dindar olmak, itaat etmek, korkmak ve çekinmek" anlamlarına gelmektedir. ${ }^{36}$ Muhâsibî”ye göre takvâ, Allah'ın hoş görmediği şeyden uzaklaşarak sakınmaktır. ${ }^{37}$ Kuşeyrî̀ye göre ise takvâ hayırlı işlerin bașı olup Allah'a itaat etmek suretiyle azaptan sakınmaktır. ${ }^{38}$

Abdülkādir-i Geylânî Gunye isimli eserinde takvâya ulaşma yollarından bahseder ve bu yollardan birinin de günahların kaynağı olan kalp günahlarını terk ile meşguliyet olduğunu belirtir. Bu da riyâ gibi günahlardan azâları sıyırmak sayesinde olur. ${ }^{39}$

Söz konusu menâkıbnâmede Abdülkādir-i Geylânî’nin açıklamalarına göre takvânın alâmetleri, her durumda gösterişi terk, riyâdan uzaklaşma ve mühim olmayan işte boş yere zahmet çekmemektir. Muttakî olan kimse Allah Teâlâ hazretlerine gösterişsiz, riyâdan uzak bir şekilde tâat ve ibadet eder. Münafık ise halk arasındaki tâatında gösteriş duygusu içinde hareket eder, halktan uzak olduğunda ise tâatı terk eder. Münafık, Hakk'ın emirlerini ifasında ve tüm hallerinde gösteriş içindedir. "Onlar namaza kalktıklarında üşenerek kalkarlar, insanlara gösteriş yaparlar, Allah'ı da pek az hatırlarlar" 40 âyetiyle münafıkların bu hali beyan edilmiştir. Münafik kendi nefsine, hevâ ve şeytanına ait hususlarda zahmet çekmez. Hz. Peygamber (s.a.s.)'in “Mü'minin ferasetinden sakının. Çünkü o Allah'ın nuruyla bakar"41 hadisinde de belirtildiği gibi nur-u ilâhî ile bakan mü’minin yanında her şeyin bir alâmeti vardır. 0 mü’minler, münafıkları “...yüzlerindeki işaretlerden kendilerini tanırsın. Kuşkusuz konuşma tarzlarından sen onları bileceksin" 42 âyetinde belirtildiği gibi simalarından fark eder, konuşma ve hareketlerinden bilirler. 43

el-A'râf 7/143.

Hasbî, Kitâb-ı Mirkāt-i Merâtib-i İlm-i Ledünnî fî Menâkıb-i Abdülkādir-i Geylânî, 138-139.

Halîl b. Ahmed, Kitâbü'l-Ayn, 4/394; Râgıb el-İsfahânî, el-Müfredât, 530.

Ebû Abdullah Hâris b. Esed el-Muhâsibî, er-Riâye li hukûkillah (Kahire: Şeriketü'l-Kuds, 1429/2008), 25.

38 Ebü'l-Kāsım Zeynülislâm Abdülkerîm b. Hevâzin b. Abdilmelik el-Kușeyrî, Tasavvuf İlmine Dair Kuşeyri Risalesi, haz. Süleyman Uludağ (İstanbul: Dergâh Yayınları, 2012), 200.

Abdülkādir-i Geylânî, el-Gunye li tâlibî tarîkı'l-Hak (Dimaşk: y.y., ts.), 1/145-146.

en-Nisâ 4/142.

Ebû İsâ Muhammed b. İsâ b. Sevre et-Tirmizî, "el-Câmi'”, el-Kütübü's-sitte (Mevsûatü'l-hadîsi'şșerîf içerisinde), haz. Sâlih b. Abdülazîz, (Riyad: Dâru's-Selâm, 2000), "Tefsîru'l-Kur'ân”, 15 (No: 3127).

$42 \quad$ Muhammed 47/30.

43 Hasbî, Kitâb-ı Mirkāt-i Merâtib-i İlm-i Ledünnî fî Menâkıb-i Abdülkādir-i Geylânî, 147-148. 
Bu açıklamalar ışığında takvâ kavramının riyadan uzaklaşma yönüne vurgu yapıldığı söylenebilir. Bununla birlikte bu kavram muttakî-münafık karşılaştırması üzerinden izah edilmiştir.

\subsubsection{Sidk}

Eski sözlüklerde "vâkıaya uygun hüküm ifade eden söz, yalanın karşıtı", "davranış ve sözlerin doğru ve gerçeğe uygun olması" diye tanımlanan sıdk kelimesi, âyet ve hadislerle diğer İslâmî kaynaklarda "hakikati konuşmak, gerçeğe uygun bilgi vermek, dürüst ve güvenilir olmak, vaadine sadâkat göstermek" anlamında mastar; "hakikati ifade eden, gerçeğe uygun olan söz, doğruluk, dürüstlük, güvenilirlik" anlamında isim olarak kullanılır. Bir şeyin objektif gerçekliği hak, bunun aslına uygun biçimde anlatılması sıdk kavramıyla ifade edilir. ${ }^{44}$ Tasavvuf ehline göre sıdk, helak olmanın söz konusu olduğu yerlerde bile hakkı söylemek, kurtuluş için yalan söylemekten başka çare olmadığı durumlarda dahi doğruyu terk etmemektir. ${ }^{45}$

Abdülkādir-i Geylânî yalanı, iman ve tasdikin zıddı olarak nitelendirerek iki zıttın bir arada olamayacağını belirtir. Yani mü'minde yalan olmaz, yalan söyleyen kişide de iman-ı kâmil bulunmaz. 0, tavsiyelerine şu şekilde devam etmiştir: "Eğer sen, "Sonunda O’na döndürüleceksiniz"46 âyetinde belirtildiği gibi Allah Teâlâ hazretlerine döneceğine inanıyorsan söz ve fiilinde sıdkını elbette gösterirsin ve amel-i sâlihte bulunursun. 0 ameli de ihlâsla sağlamlaştırmaya gayret edersin. Riyâyı terk edersin. Eğer sen sıdk ve ihlâsı gözetir ve korursan dilini de yalan ve iftiradan korursun. Böylece imanın sıhhat ve kuvvet bulmuş olur. ${ }^{47}$ Sıdk sahibini cennete yaklaştırır; yalan ise sahibini cehenneme yaklaştırır." 48

Abdülkādir-i Geylânî, sıdk hakkında kendisine yöneltilen soru üzerine sıdkın türlerinden bahsederek konuyu izah etmiştir. Ona göre ef'âlde sıdk, zihinde ve kalbin derinliklerinde gizli olan esrârın, söz söyleneceği zamanda, söz ile uyumudur. Akvâlde sıdk, doğru söz söylemektir. Ahvâlde sıdk, havâtırı doğruluk ve adalet üzere ikâme ile hâl sahibi olmaktır. ${ }^{49}$

$\mathrm{Bu}$ açıklamalar birlikte değerlendirildiğinde Abdülkādir-i Geylânî sıdk kavramını iman-amel çerçevesinde ele alarak ihlâsın önemine vurgu yapmıştır. Ona göre sıdk konusunun kemâl noktası ise söz, fiil ve hallerde doğruluk üzere hareket etmektir.

\footnotetext{
44 Mustafa Çağrıcı, "Sıdk”, Türkiye Diyanet Vakfi İslâm Ansiklopedisi (İstanbul: TDV Yayınları, 2009), 37/ 98; Ayrıca bk. Râgıb el-İsfahânî, el-Müfredât, 277; Ebü’t-Tâhir Mecdüddin Muhammed b. Yakub b. Muhammed el-Fîrûzâbâdî, Besâir zevi't-temyîz fî letâifi'l-Kitâbi'l-Azîz, thk. Ali en-Neccâr (Beyrut: Mektebetü'l-İlmiyye, ts.), 3/396. Bk. Ebü'l-Hasen Alî b. Muhammed b. Alî es-Seyyid eş-Șerîf el-Cürcânî el-Hanefî, Mu'cemü't-ta'rîfât, thk. Muhammed Sıddîk el-Münşâvî (Kahire: Dâru'l-Fazîlet, t.s.), 113.

Yûnus 10/56.

Hasbî, Kitâb-ı Mirkāt-i Merâtib-i İlm-i Ledünnî fî Menâkıb-i Abdülkādir-i Geylânî, 162.

Hasbî, Kitâb-ı Mirkāt-i Merâtib-i İlm-i Ledünnî fì Menâkıb-i Abdülkādir-i Geylânî, 165.

Hasbî, Kitâb-ı Mirkāt-i Merâtib-i İlm-i Ledünnî fî Menâkıb-i Abdülkādir-i Geylânî, 131-132.
} 


\subsubsection{Tevekkül}

Tevekkül, bir kimsenin kendini Allah'a teslim etmesi, rızkında ve işlerinde Allah'ı kefil bilip sadece ona güvenip dayanması, insanların elindekilere tamah etmemesidir. ${ }^{50}$ Hamdûn el-Kassâr (ö. 271/884)'a göre tevekkül, Allah'a sımsıkı sarılmak ve ona itimat etmektir. ${ }^{51}$ Herevî ise "işi tamamıyla mâlikine havale edip vekillik hususunda yalnız ona güvenmek" olarak tevekkülü tanımlamaktadır. ${ }^{52}$

Abdülkādir-i Geylânî'ye göre tevekkül, Allah'tan gayrı her şeyden alâkaları kesmek ve meşguliyeti yalnız Allah Teâlâ Hazretleri'ne yönelterek O'na mahsus kılmaktır. Kulun, Hak'tan gayrısından talep etiği şeyi rıâ-yı ilâhî için terk ederek yalnızca Allah'tan istemesidir. Ayrıca, Cenâb-ı Hakk'a olan tevekkül ve tefvîz sebebiyle Hak'tan başka kimseden bir șey beklememek ve kimseye ihtiyaç duymamaktır. Tevekkül, güvenin sabit ve sağlam olmasıdır. “... Biz paylaştırdık...”53 hükmünce ilâhî takdire ve ezelî ilme eksiklik veya fazlalık isnat etmemektir. ${ }^{54}$

“Çünkü biz ona şah damarından daha yakınız"55 hükmüne göre kullarına şah damarından yakın olan ganî-yi mutlak hazretleridir. İtimat ancak O'na olmalı, ihtiyaçlar O'na arz edilmelidir. Âhireti dünyaya öncelemeli, âhiret için hayır ve hasenâta gayret edilmeli ve kabre ulaşmadan önce kabir mâmur edilmelidir. Cüz'î irade, Allah'ın iradesine terk edilmelidir. Aynı zamanda kendi tedbirine değil Hakk'ın takdirine razı olunmalıdır. 56

Abdülkādir-i Geylânî'nin belirttiğine göre arzulanan nimetler konusunda yalnızca Allah'a tevekkül edilmelidir. Kişi Allah'a olan hakiki kulluğu, ibadetleri ve tevekkülü neticesinde ind-i ilâhîde olan hazine ve ihsanlara kavuşur. İnsana düşen ise bu nimetlerin şükrü olarak infakta bulunmaktır. ${ }^{57}$

Âyet-i kerimede “...susamış kimsenin geniş düzlüklerde görüp su zannettiği serap gibidir; sonunda gelip ona ulaşınca orada bir şey bulamaz..." 58 diye beyan olunduğu üzere susuz kimseler çöldeki serabı görüp su zannederler, ümitle ona doğru giderler. Ona yaklaşınca bir şey bulamazlar ve o şeyin bir nesne olmadığını anlarlar. Muvahhit ve Cenâb-ı Hakk'a itimat eden kimsenin tevhid anlayışının kuvvetlenmesiyle birlikte anne, baba, mal ve makam arzusu kalmaz ve onda hiçbir şeye meyil olmaz. 0 muvahhitte Allah'a bağlılık dışında hiçbir şey bulunmaz. ${ }^{59}$

Abdülkādir-i Geylânî, tevekkülün kalp üzerindeki etkisinden de bahsetmiştir. Her kim Müslümanlıkta kuvvet ve kudretini arzu ediyorsa Cenâb-ı Hakk'a mütevekkil

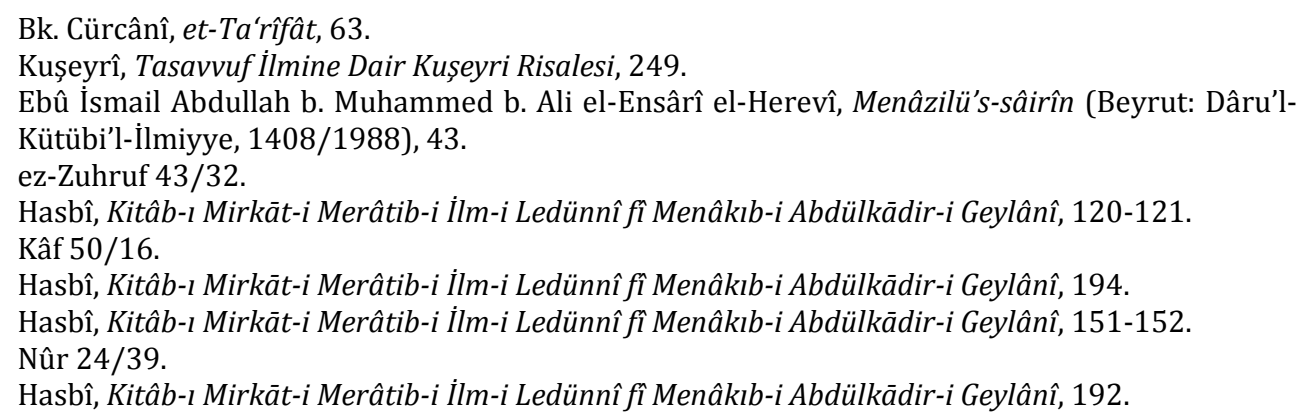


olmalıdır. Zira tevekkül, kalbi tashih eder, kuvvetlendirir ve kalbe hidayet bahşeder. Onu doğru yola irşat eder. Paraya ihtimam ve itimat kişiyi acze ve kahra dûçâr eder. Allah Teâlâ hazretlerine tevekkül edilmelidir. Zira Allah Teâlâ fazl-ı ilâhiyesinden lütuf ve ihsan eder.60

Abdülkādir-i Geylânî'nin, menâkıbnâmenin farklı yerlerinde tevekkül, tevekkülün hakikati, tevhid-tevekkül ilişkisiyle ilgili açıklamaları yer almıştır. Böylece o, tevekkülün imanla ilişkini ortaya koymuştur. Abdülkādir-i Geylânî, tevekkülün kalple ilişkisine ağırlık vermekle birlikte, tedbir ve amel yönüne de dikkat çekmiştir. 0 , tevekkülün iman ve amel olmak üzere iki yönünü de ortaya koymak suretiyle sûfîlerin genel anlayışını yansıtmış; tevekkülün pasif bir şekilde bekleme olmadığını ortaya koymuştur. Ayrıca tevekkül neticesinde elde edilen nimetlerin şükrü olarak infakta bulunulmasını da tavsiye etmiştir. Abdülkādir-i Geylânînnin, konuyu daha anlaşılır hale getirmek adına örnek ve benzetmelerden faydalandığı aynı zamanda konu izahında hadis ve âyetlere de sıklıkla yer vererek konuyu derinleștirdiği görülmüştür.

\subsubsection{Sabır}

Sabır, Arapçada gerekli durumlarda nefsi hapsetmek, kendini tutmak, iradesine hâkim olmak demektir. Ayrıca "intizar etme, bekleme ve gözleme" eylemleri "sabr" sözcügüyle ifade edilmektedir.61 Nefsi tâate, emir ve yasaklara uymaya zorlamak şeklinde tarif edilen sabır bütün makamları, halleri, huyları, amelleri içerir. Çünkü bütün bunlar, ancak nefsi şükretmeye yönlendirmek ve onu düzeltmenin güçlügüne katlanmak ve alıştırmak için zorlamayla gerçekleşir. Onun için hiçbir şey sabrın haricinde değildir, çünkü sabır hüküm itibarı ile makamların en umumisi, tesir itibarı ile de huyların en kapsamlısıdır.62 Sûfî, riyâzât ve mücâhede için sabrı bir düstur olarak benimsemelidir. Zira nefisle mücadelenin en mühim şartı sabırdır. Sabır, kulun iradesi içinde olduğu gibi, iradesi dışında da olur. Allah Teâlâ'nın emir ve yasaklarına riayette sabır irade içi, Hakk'ın hükmüne teslim olmak ise irade dışı sabırdır.63

Abdülkādir-i Geylânî'ye göre sabır, bela geldiğinde güzel bir edeple ona tahammül ederek, gücenme, sıkıntı gibi hallerde bulunmamaktır. "Biz şüphesiz Allah'a aidiz ve şüphesiz O'na döneceğiz"64 âyetinde belirtildiği gibi kişinin kendini ve işlerini Hakk'a teslim ederek hem zâhiren hem bâtınen muzdarip olmayıp daima sebat üzere hareket etmesidir. Yani salik, kendisine isabet eden kazâ ve belâ ile kederlenmeyerek onun acısını -kitap ve sünnet ahkâmı üzere- kolaylık telakkî etmeli ve o acıya alışarak ondan korkmamalıdır. Abdülkādir-i Geylânî sabır konusunu kısımlara ayırarak konuyu detaylandırır. Bunlardan birisi Sabrullahtır. Yani ilâhî

Hasbî, Kitâb-ı Mirkāt-i Merâtib-i İlm-i Ledünnî fî Menâkıb-i Abdülkādir-i Geylânî, 184.

İbn Manzûr, Lisânü'l-Arab, 2391.

Abdürrezzâk Kâşânî, Tasavvuf Sözlügü, çev. Ekrem Demirli (İstanbul: İz Yayınları, 2004), 326.

Selçuk Eraydın, Tasavvuf ve Tarikatlar (İstanbul: MÜ İlâhiyat Vakfı Yayınları, 2004), 165-166. el-Bakara 2/156. 
emirleri yerine getirmek ve ilâhî yasaklardan kaçınmak üzerine sabırdır. Diğeri de Sabr-ı mâ-Allah'tır ki gelen hükme sükût ve sükûn göstermek ayrıca yoksulluğun nüzûlü esnasında "Bilmeyen kimseler, iffetlerinden dolayı onları zengin zanneder"65 hükmünce hareket ederek fakirlik ve belaya karşı yüz ekşitmemek, mahrumiyet belirtisi göstermemek ve kanaat sahibi olmaktır. Allah Teâlâ'nın vaadine meyil göstermek ve onda eksiklik olmadığını yakinen tasdik etmektir. Dünyadan âhirete seyr ü sefer, mü'min için kolaydır. Salik, nefsinden fâni olarak Allah'a doğru seyr ü sülûk etmelidir. Sabr-ı mâ-Allah, Sabrullahtan daha şiddetlidir. Fakir olup sabreden kimse, zengin olup şükreden kimseden efdaldir. Fakir olup şükreden ise ikisinden de efdaldir. Fakir olup sabreden ve şükreden kimse ise bunların hepsinden efdaldir. Hakk'ı bilen, Hakk'ın aşık ve muhibbi olan, kalpleri bu aşk ve sevgiyle dolu olan has kullar, bela ve musibetlerle daha fazla imtihan olunur. ${ }^{66}$

Abdülkādir-i Geylânî, Fethu'r-rabbânî isimli eserinde de sabrı benzer şekilde yorumlamıştır. Ona göre, sabır belanın geldiği kaynağı görüp, ondan sızlanmamak, başkalarına beladan dolayı şikayette bulunmamaktır. Belanın gerisindeki hakikatleri görmektir. Belanın Hak canibinden geldiğini bilmek, dolayısıyla Hakk'a ve onun kazâ ve kaderine muvafakat etmektir. ${ }^{67}$ Allah'ı bilen kişi onun yarattıklarına asla şikayette bulunmaz. ${ }^{68}$

Muttakî ve mütevekkil olmak için sabra devam edilmelidir. Zira her hayrın esası sabırdır. Sabır hususundaki gayret kuvvetli olursa Allah Teâlâ hazretleri o sabrın mükafatı olarak dünyevî ve uhrevî kendi muhabbetini ve yakınlığını o kalbe yerleştirir. Her sevap için mizan vardır ancak sabrın sevabı için mizan yoktur. 0 sabrın mükafatı cennettir. Orada göz görmemiş ve kulak işitmemiş nimetler kendisine ihsan edilir. 69

Cenâb-ı Hak bir kulu hakkında hayır dilediği zaman o kulun beșeriyetini ve enâniyetini kaldırır. Kul, bu yolda rastlayacağı ilâhî imtihanlara sabrederse o kulun derecelerini terfi ettirir, inâyet ve nimetlerini ona verir. Onun vücûd-ı mecâzisini yok eder, onu hakkânî bir vücûd ile canlı tutar. ${ }^{70}$

Abdülkādir-i Geylânî, gayretsiz ve amelsiz bir şekilde mükafat ve dereceler arzu etmekten kaçınmak gerektiğini belirtir. Rasûlullah'ın sahâbelerine bakılmalı ve onların davranışları örnek alınmalıdır. Zira onlar dünya ve âhirette ulaştıkları derece, makam ve kerâmetlere ancak mücâhededen sonra nail oldular. Onlar sıcağın şiddetli zamanında, kızgın taş üzerinde namazlarını kılarlardı. 0 taşların kızgınlığı onların ellerini yakardı. Yağmur yağdığı zamanda üzerlerine giymiş oldukları deri kokardı.

el-Bakara 2/273.

Hasbî, Kitâb-ı Mirkāt-i Merâtib-i İlm-i Ledünnî fî Menâkıb-i Abdülkādir-i Geylânî, 128-129.

Abdülkādir-i Geylânî, el-Fethu'r-rabbânî ve'l-feyzu'r-rahmânî, nșr. Muhammed Sâlim el-Bevvab (Beyrut: y.y., ts.), 174

Abdülkādir-i Geylânî, el-Fethu'r-rabbânî, 263.

Hasbî, Kitâb-ı Mirkāt-i Merâtib-i İlm-i Ledünnî fỉ Menâkıb-i Abdülkādir-i Geylânî, 185-186.

Hasbî, Kitâb-ı Mirkāt-i Merâtib-i İlm-i Ledünnî fî Menâkıb-i Abdülkādir-i Geylânî, 150. 
Onlar açlığa sabrederlerdi. Onların bu mücâhede ve sabırları âhirette selâmetlerine sebep oldu. ${ }^{71}$

Abdülkādir-i Geylânî, sabrı tanımlayarak önemi ve mükafatından bahsetmiștir. Ona göre başa gelen musibet ve belalara karşı rızâ halinde bulunulmalı ve çekilen sıkıntılara sabredilmelidir. Böylece sabrın neticesinde Allah'a kurbiyyet elde edilir. 0, ayrıca sabır-tevekkül-takvâ ilişkisine değinmiş ve sabrın türlerini de açıklamıştır. Sabır ve şükür sahibi fakir ve zengin kişileri karşılaştırarak sonunda bunlar içinde en efdalinin hem sabreden hem şükreden fakir olduğunu belirtmiştir.

\subsubsection{Rızâ}

Rızâ, sözlükte "hoşnut ve memnun olmak, tasvip etmek, beğenmek, itiraz etmemek" anlamlarına gelmektedir. ${ }^{72}$ Tasavvufta ise rızâ iki yönlü olarak ele alınmakta olup hem Allah hem de kul için söz konusu olduğu bilinmektedir. Kulun Allah'tan razı olması, Allah'ın takdirine hoşnutsuzluk göstermemesi ile tezâhür eder. Allah'ın kulundan razı olması ise kulun, Allah'ın emirlerine itaat etmesi ve yasaklarından sakınması neticesindedir. ${ }^{73}$ Zünnûn el-Mısrî̀ye (ö. 245/859 [?]) göre "Şu üç husus rizâ alâmetidir: Kazânın tesiri ile meydana gelecek olan hadiseden evvel iradeyi terk etmek, kazâ ve kaderin hükmü ortaya çıtıktan sonra bu hükmün acılığını hissetmemek ve musibetin içinde iken ilâhî sevginin heyecanını hissetmek."74

Abdülkādir-i Geylânî, kalpte tereddütün kalkmasıyla birlikte ezelde Allah'ın ilminde olan ve Allah'tan gelen bir kazânın nüzûlüne kalbin hazır olmasını rızâ olarak nitelendirir. Başka bir ifade ile rızâ, kazâ meydana geldiği vakitte, kulun kalbinin o kazânın sona ermesine meyletmemesidir. ${ }^{75}$

Bu açılklamalara göre rızâ kavramının sabır ve tam bir teslimiyet boyutuyla ele alındığı görülmektedir. Bu durum, kavramların birbiriyle ne kadar ilintili olduğunu da ortaya koymaktadır. Ayrıca kavramların çok katmanlı yapısına da işaret etmektedir. Abdülkādir-i Geylânî'nin rızâ hakkındaki yorumuyla Zünnûn el-Mısrî'nin yorumunun örtüştüğü görülmektedir.

\subsubsection{0. Şükür}

Nimeti tasavvur ve izhar olarak da tarif edilen ${ }^{76}$ şükür bir ahlak ve tasavvuf terimi olarak ise Allah'tan gelen nimetten dolayı minnettarlığı ifade etme, nimete söz, gönül veya fiil ile mukabelede bulunma, Allah'a itaat edip günah işlemekten uzak durmak suretiyle nimetin gereğini yapma anlamında kullanılır. ${ }^{77}$ Herevî şükrü, nimeti

\footnotetext{
Hasbî, Kitâb-ı Mirkāt-i Merâtib-i İlm-i Ledünnî fî Menâkıb-i Abdülkādir-i Geylânî, 166. İbn Manzûr, Lisânü'l-Arab, 17/1663.

Bk. Râgıb el-İsfahânî, el-Müfredât, 197; Cürcânî, et-Ta'rîfât, 96.

Kușeyrî, Tasavvuf İlmine Dair Kușeyri Risalesi, 278.

Hasbî, Kitâb-ı Mirkāt-i Merâtib-i İlm-i Ledünnî fî Menâkıb-i Abdülkādir-i Geylânî, 133

Râgib el-İsfehânî, el-Müfredât, 461.

Cürcânî, et-Ta'rîfât, 109.
} 
bilmek ve itiraf etmek olarak anlamlandırmakta ve şükrün üç şekli olduğunu belirtmektedir: Nimeti bilmek, nimeti kabul etmek ve nimeti övmek.78

Abdülkādir-i Geylânîye göre şükrün hakikati alçakgönüllülüktür. Ona göre şükür, verilen nimeti kabul ve tasdik etmek; nimetin klymetini ve iyiliğini takdir etmektir. Ayrıca şükrü, şükreden kimsenin, ilahî ihsan ve lütufları müşâhede etmesi olarak da nitelendirir. Bu müşâhededen sonra nimetten nimet vereni görmeye terakkidir ki bu, eserden müessiri istidlâle yükselmedir. Abdülkādir-i Geylânî şükrün birtakım bölümlere ayrıldığını belirtir. Onlardan biri şükr bi'l-lisândır. Şâkirin, tevâzuyla nimet verenin nimetini itirafıdır. Diğeri, şükr-ü bi'l-erkândır. Şâkirin huşû, sekînet ve vakar ile vasıflanmasıdır. Bir diğeri de şükr bi'l-kalptir. Şâkirin hürmeti koruması, ta'zîm ve yüceltmeye devam etmesi ve o suretle nefsi hapsetmesidir. ${ }^{79}$

Şâkir, mevcudiyet üzere şükreden kimsedir. Hâmid ise yasakta bağışlamayı ve zararda faydayı müşâhede eden kimsedir. Sonrasında hâmidin nazarında fayda ve zarar eşit olur. ${ }^{80}$

Bu açıllamalara göre Abdülkādir-i Geylânî, şükür kavramını tanımlamış, hakikatini ifade etmiştir. Şükrü kalp, dil ve davranışa yansıması boyutuyla ele alarak izah etmiştir. Şükür, kalpte başlayan; söz ve davranışla zâhire yansıyan önemli bir değerdir. Bununla birlikte Abdülkādir-i Geylânî, şükür ve hamd sahibi kimseleri karşılaştırarak farkı ortaya koymuştur.

\subsubsection{Hayâ}

Sözlükte "utanma, çekinme ve tevbe" gibi anlamlara gelen hayâ, bir ahlak terimi olarak "nefsin çirkinliklerini utanarak ve kınanma korkusuyla terk etmesi" anlamına gelmektedir. ${ }^{81}$

Abdülkādir-i Geylânîye göre hayâ, ilâhî emirleri yerine getirmediği müddetçe kişinin Allah'tan bir talepte bulunmaya yüzünün olmamasıdır. Ayrıca o kimsenin, layık olmadığını bildiği nesne ile Allah'a teveccüh göstermekten ve müstehak olmadığı şeyi Allah Teâlâ'dan temennî etmekten utanmasıdır. Kişinin, günahları havftan değil hayâdan dolayı terk etmesidir. "Şüphesiz Allah kalplerde olanı bilmektedir"82 âyet-i celîlesi hükmünce Allah Teâlâ Hazretleri'ni kalbi ve esrârı üzerine muttali' görerek, ondan utanmaktır. Hayâ, kulun kalbiyle heybet-i ilâhiyye arasındaki hicabın kaldırılmasından, inkişâfın oluşmasından meydana gelir. ${ }^{83}$

Görüleceği üzere hayâ kavramı, "Allah'tan utanma” anlam mertebesinde ele alınarak vurgulanmıştır. Aynı zamanda ilâhî emirleri yerine getirme konusuyla bağlantılı olarak ele alınmış ve bu minval üzere açıklanmıştır. Günahların havftan

Herevî, Menâzilü's-sâirîn, 53.

Hasbî, Kitâb-ı Mirkāt-i Merâtib-i İlm-i Ledünnî fî Menâkıb-i Abdülkādir-i Geylânî, 127-128.

Hasbî, Kitâb-ı Mirkāt-i Merâtib-i İlm-i Ledünnî fì Menâkıb-i Abdülkādir-i Geylânî, 127-128.

Râgıb el-İsfahânî, el-Müfredât, 270.

Âl-i İmrân 3/119; el-Mâide 5/7; Lokmân 31/23.

Hasbî, Kitâb-ı Mirkāt-i Merâtib-i İlm-i Ledünnî fì Menâkıb-i Abdülkādir-i Geylânî, 139-140. 
dolayı değil hayâdan dolayı terk edilmesi gerektiği ifade edilerek bu iki kavram arasındaki ilişkiye de işaret edilmiştir.

\subsubsection{Vefâ}

Sûfîler, bezm-i elestte Allah'ın rab olduğunu ikrar etmeyi ahid, bu taahhüde bağlı kalmayı da ahde vefa kabul etmișlerdir. ${ }^{84}$ Avam bu taahhüdü ibâdet, havas ubûdiyyet, havâssü'l-havâs ubûdet şeklinde ifa eder. İnsanın korktuğundan emin, umduğuna nâil olması için Allah'a tapması ibâdet; korku, ümit ve karşılık söz konusu olmaksızın emre sırf emir olduğu için uyması ubûdiyyet (kulluk); buna kendi kuvvetini ve iradesini de katması ubûdettir (has kulluk). Bezm-i elestte verilen ikrar ve ahid bu üç tarzda ifa edilmiş olur. ${ }^{85}$

Abdülkādir-i Geylânî̀ye göre vefâ, Allah'ın emir ve hükümlerine, hukukuna riayet etmek; Allah tarafından haram ve yasak kılınan şeyleri görmemek, düşünmemektir. “Bunlar, Allah’ın koyduğu kurallardır bu sebeple onları çiğnemeyin. Her kim Allah'ın koyduğu kuralları çiğnerse işte onlar zalimlerin ta kendileridir" 86 âyetinde belirtildiği üzere gerek fiilen gerek kavlen Allah'ın sınırlarını muhafaza etmeye ve her durumda Hakk'ın rızâsını kazanmaya gayret göstermektir." 87

Açıklamalar ışığında vefâ kavramının, Allah'ın emir ve yasaklarına uyma bağlamında ele alınarak rızâ konusuyla da irtibatlandırıldığı görülmektedir.

\section{Tahakkuka Dair Kavramlar}

Tasavvufun diğer boyutu olan "Tahakkuk" ise ma'rifet, işâret ve bilgi boyutudur. 88 Tasavvufî tecrübeye dair konuları da ihtiva etmektedir.

Makalenin bu bölümünde, mezkûr menâkıbnâmede yer alan "Tahakkuka Dair Kavramlar" hakkındaki Abdülkādir-i Geylânî’nin görüş ve açılklamalarına yer verilmiştir.

\subsection{Tasavvufî Tecrübeye Dair Kavramlar}

\subsubsection{Muhabbet}

Muhabbet, kişinin hayırlı gördüğü şeyi istemesi yahut sevmesi demek olup buğzun zıddıdır. ${ }^{89}$

Tasavvufun öne çlkan konularından olan muhabbet hakkında Cüneyd-i Bağdâdî muhabbetin "kalbin meyli" olduğunu belirterek bu meylin, kulun gönlünün tabiî olarak, tekellüfsüz bir şekilde Allah'a ve Allah rızâsı için olan şeylere

Bk. el-A'râf 7/172.

Ebû Muhammed Sadrüddîn Rûzbihân b. Ebî Nasr el-Baklî, Meşrebü'l-ervâh, nșr. Nazif M. Hoca, (İstanbul: y.y., 1974), 43-73.

el-Bakara 2/229.

Hasbî, Kitâb-ı Mirkāt-i Merâtib-i İlm-i Ledünnî fî Menâkıb-i Abdülkādir-i Geylânî, 133.

Hasan Kâmil Yılmaz, "Tasavvufla İlgili Sorular ve Cevaplar" (el-Luma', İslâm Tasavvufu içerisinde), 444.

89 Râgıb el-İsfahânî, el-Müfredât, 105. 
yöneleceğini ifade etmiștir. ${ }^{90}$ Kuşeyrî’ye göre, Allah'ın kuluna karşı muhabbeti, kuluna yakınlık ve yüce haller tahsis etmesidir. Kulun rabbine karşı olan muhabbeti ise kulun kalbinde bulunan ve sözlerle ifade edilmesi gayet güç olan bir haldir. Bu hal insanı Allah'ı tâzim etmeye, onun rızâsını her şeye tercih etmeye götürür. ${ }^{11}$ Hücvirî’ye göre Allah'ın kulu sevmesi, ona bol bol nimet ihsân etmesi, dünya ve âhirette sevap vermesi, cehennemden onu emin kılması, yüce haller ve yüksek makamlar ikram etmesidir. Kulun Allah'ı sevmesi ise sevgilinin rıâsını talep etmek, zikretmeyi alışkanlık haline getirmektir. Ülfet ve ünsiyet ettiği sultanına yönelmek, sultanın hükmüne riayet etmek, Hak Teâlâ'yı kemâl vasıflarıyla tanımak için, O’nu yüceltmek manasına gelmektedir. ${ }^{92}$

Abdülkādir-i Geylânî’ye göre muhabbet, aşıkların kalplerinde oluşan karışık bir haldir ve bu hal mahbûbun etkisiyle gerçekleşir. Aşık ve muhip bu haldeyken, dünya onun için dar ve sıkıntılı olur. Muhabbet öyle bir sekr ve sarhoşluktur ki muhabbetin meydana gelmesiyle birlikte o halden sahv ve aylklık vaki olamaz. Muhabbet öyle bir zikir ve fikirdir ki onu izâle etmek mümkün olmaz. Muhabbet ızdıraplı ve kararsız olmaktır; onda sükûn, karar, itminan hasıl olmaz. Muhabbet, mahbûba karşı hissedilen samimi bir sevgidir. Bu durum tercih ile değil belki mecburiyet ve çaresizlik ile vakidir. Muhabbet, mahbûbdan başkasını görmemek, bilmemek ve tanımamaktır. Ayrıca muhabbet, aşı ve muhip için hem mahbûbdaki heybet, haşmet ve azimet sebebiyle hem de kendisindeki fakr ve mahbûba olan hakiki ihtiyacına dayalı olarak muhibbin kendisini mahbûbda yok etmesidir. Aşılar ve muhipler, sekr zümresine dahildirler bu sebeple onlar ayllıp sahva gelmezler. Ancak mahbûblarını müşâhede ile ayılırlar ve sahv halini bulurlar. Muhipler öyle bir devaya muhtaçtırlar ki onların şifa ve ilaç bulmaları ancak mahbûbu düşünmek ile hasıl olur. Muhipler hayret halinde oldukları için mevlâlarından başkasına yakınlık duymazlar, onu zikretmeden söz söylemezler. Ondan başka hiçbir davet ve davetçiye de icabet etmezler. ${ }^{93}$ Muhip, mahbûbundan bir şey gizlemez ve mahbûbunu her şeyin üzerinde görüp ondan hiçbir şeyini esirgemez.94

Rasûlullah'a muhabbetin şartı fakrdır ve Allah Teâlâ hazretlerine muhabbetin şartı da belaya sabırdır. ${ }^{95}$

Abdülkādir-i Geylânî, Cilâü'l-hâtır adlı eserinde muhabbeti iki kısma ayırmaktadır: 1) Iztırârî (mecburi olarak, istemeden). Bu çok az kimsede olur. Hak o kimselere nazar eder. Onları sever, onları sevgisine duçar eder. 2) İhtiyârî (isteyerek). Çoğunluk için aslolan budur. Onlar Allah'ı onun halkına tercih ederler. Tercihlerini

\footnotetext{
90 Ebû Bekr Muhammed b. İbrâhim el-Buhârî el-Kelâbâzî, et-Taarruf li-mezhebi ehli't-tasavvuf, haz. Ahmed Şemsüddin (Beyrut: Daru'l-Kütübi'l-İlmiyye, 1413/1993), 128.

Kușeyrî, Tasavvuf İlmine Dair Kușeyri Risalesi, 405.

Hücvîrî, Keșfü'l-mahcûb (Hakikat Bilgisi), 370.

Hasbî, Kitâb-ı Mirkāt-i Merâtib-i İlm-i Ledünnî fì Menâkıb-i Abdülkādir-i Geylânî, 113-114.

Hasbî, Kitâb-ı Mirkāt-i Merâtib-i İlm-i Ledünnî fî Menâkıb-i Abdülkādir-i Geylânî, 154-155.

Hasbî, Kitâb-ı Mirkāt-i Merâtib-i İlm-i Ledünnî fî Menâkı b-i Abdülkādir-i Geylânî, 154-155.
} 
Hak tarafından yana kullanırlar. Kendilerini Hakk'ın sevgisine bağlar ve onun muhabbetini kazanmak için çaba harcarlar. ${ }^{96}$

Yukarıdaki açıklamalarda görüleceği üzere Abdülkādir-i Geylânî, menâkıbnâmede muhabbet konusunu izah ederken muhabbetin ıztırâri (mecburi) yönüne vurgu yapmıştır. Ona göre muhabbet, bütün zihin ve kalp yoğunluğunu sevilene yöneltmek, ondan başkasını düşünmemek ve onu zikretmektir. Muhip için tek gerçek vardır o da mevlâsıdır. Muhip mevlâsıyla ünsiyet kurduğu için kalbinde mevlâsından başkasına yer yoktur. Abdülkādir-i Geylânî, muhabbet konusunu tasavvufî kavramlardan olan sahv, sekr, fakr ve sabır terimleri ile izah etmiștir.

\subsubsection{Müşâhede}

Sözlükte "görmek, şâhitlik etmek ve gözlemlemek" anlamlarına gelen müşâhede ${ }^{97}$ tasavvufta Allah'ın zuhur ve tecellilerini görmeyi, seyir ve temaşa etmeyi ifade eder. ${ }^{98}$ Hücvîrî’nin ifade ettiğine göre sûfîlerin müşâhede sözünden muradı Allah'ı ve O'nun tecellilerini kalp ile görmektir. Çünkü müşâhede halinde bulunan zat, tenha yerde de topluluk içinde de Hak Teâlâ'yı kalp ile görür. ${ }^{99}$ Kitabü'l-Müşâhede isminde bir eser yazan Ebû Osman Mekkîye göre müşâhede, araya setr ve inkıta hali girmeden tecelli nurlarının art arda salikin kalbine gelmesidir, peş peșe çakan bir şimşek farz edilmesi gibi. Nitekim karanlık bir gecede şimşeğin sürekli bir şekilde kesintisiz olarak çaktığı farz edilse; gece, gündüz gibi aydınlık olur. Bunun gibi tecelli halinin devamlı olması sebebiyle kalbin gecesi ortadan kalkar, gayb net olarak görülür. 100

Abdülkādir-i Geylânî̀ye göre müşâhede, ilâhî hakikatleri Hak mârifetiyle anlamak, idrak etmek ve Hakk'ı düşünmektir. Ayrıca Allah Teâlâ Hazretleri'nin gayb âleminden haber verdiklerini, yakîn ilmi ile kalplerin bilmesidir.101

Abdülkādir-i Geylânî'nin açıklamalarına göre müşâhede, ilâhî hakikatleri basiret gözüyle görme ve idrak etme anlamına gelmektedir. Abdülkādir-i Geylânî müşâhede kavramını, mârifet ve ilm-i yakîn kavramlarıyla da ilintili şekilde izah etmiştir.

\subsection{3. İlim}

Yakîn sözlükte, "sabit olmak, durulmak, sükûnete kavuşmak, şüphe bulundurmayan bilgi, kesin gerçek" gibi anlamlara gelmektedir.102 İlim ise bilmek

\footnotetext{
96 Abdülkādir-i Geylânî, Cilâü'l-hâtır min kelâmi'ş-şeyh Abdilkādir fi'z-zâhir ve'l-bâtın (İstanbul: İ.Ü. Merkez Kütüphanesi, Arapça, 2325), 84b.

Halîl b. Ahmed, Kitâbü'l-Ayn, 2/363.

98 Bk. Süleyman Uludağ, "Müşâhede", Türkiye Diyanet Vakfı İslâm Ansiklopedisi (İstanbul: TDV Yayınları, 2006), 32/152.

99 Hücvîrî, Keșfü'l-mahcûb (Hakikat Bilgisi), 393.

100 Kușeyrî, Tasavvuf İlmine Dair Kuşeyri Risalesi, 169-170.

101 Hasbî, Kitâb-ı Mirkāt-i Merâtib-i İlm-i Ledünnî fî Menâkıb-i Abdülkādir-i Geylânî, 140.

102 Bk. Cürcânî, et-Ta'rîfât, 217.
} 
demektir. Tasavvufî anlamda ilim mârifet, irfan, salikin kendini bilmesi'103 gibi anlamlara gelmektedir. Tasavvufta ilim üç kısma ayrılır: İlme'l-yakîn, burhan ve delille elde edilen bilgidir. Ayne'l-yakîn, beyân hükmünde olan bilgidir, keșf ve ilhamla elde edilir. Hakka'l-yakîn, âyân beyân niteliğinde olan bilgidir ve müşâhede ile elde edilir. İlme'l-yakîn, akıl sahibi olanlara; ayne'l-yakîn, zevk ve keşfe dayanan ilim sahibi olanlara; hakka'l-yakîn ise mârifet sahibi olanlara mahsustur. ${ }^{104}$

Abdülkādir-i Geylânî yakîn kavramını, gaybın hükümlerinin sırlarına vâkıf olmak, hakikatine ermek olarak tanımlamaktadır. ${ }^{105}$ İlm-i yakîn ise nazar ve istidlâl cihetiyle haber ile mârifet arasını birleştirmekten ibarettir. Mesela bir şey, ilmen bilinip kalben de mârifet ile kabul edildiğinde ilm-i yakîn meydana gelir. ${ }^{106}$ Yani ilm-i yakîn, delillerle elde edilen ilim ile mârifetten meydana gelen bilgi türüdür.

Abdülkādir-i Geylânî̀ye göre mü'minin kalbine başlangıçta zuhur eden; necmi hükümdür sonra kamer-i ilimdir sonra ise şems-i mârifettir. Bu surette o mü'min, necm-i hüküm ile dünyaya nazar eder, kamer-i ilmin nuruyla âhirete nazar eder ve şems-i mârifetin ziyasıyla mevlâya nazar eder. ${ }^{107}$ O, ilim ve mârifet konularını izah ederken benzetmelerden istifade ederek anlatımı zenginleştirmiştir.

Abdülkādir-i Geylânî, ilmin hayat ve cehaletin ise ölüm olduğunu belirterek ilmin değerine vurgu yapar. İlmiyle âmil, amelinde muhlis olan ve Allah Teâlâ hazretlerinin kullarına ilim öğretirken külfet ve meşakkate sabreden âlim için ölüm yoktur. Zira o âlim vefatıyla birlikte Allah Teâlâ hazretlerine kavuşur ve hayatı onunla devam eder, bekâ bulur. ${ }^{108}$ Abdülkādir-i Geylânî, ilmi hayatla özdeșleştirmek suretiyle önemine vurgu yapmakla birlikte ilmin ancak amelle desteklendiğinde anlam ve değer kazanacağını da ifade etmiştir. İlmi canlılı; cehaleti ise yokluk olarak nitelendirmiş böylece ilmin insan hayatındaki vazgeçilmezliğine dikkat çekmiştir.

\subsubsection{Havf ve Recâ}

Havf, hoşlanılmayan bir durumun başa gelmesinden veya arzulanan bir şeyin elde edilememe ihtimalinden dolayı duyulan kaygı ve korku anlamında kullanılmaktadır. ${ }^{109}$ Tasavvufta ise kelime anlamıyla doğrudan irtibatlı olarak insanın Allah katındaki durumu hakkında hissettiği korku ve kayglları ifade etmektedir.110 Kuşeyrî, havfin geleceğe dair bir korku olduğunu söylemektedir. Nitekim insan ya hoşlanmadığı bir şeyin başına gelmesinden ya da istediği bir şeyi kaçırmaktan korkar. Bu iki korku da istikbale dairdir. Allah'tan korkmak ise O'nun dünyada ve âhirette

103 Uludağ, Tasavvuf Terimleri Sözlüğü, 184.

104 Kuşeyrî, Tasavvuf İlmine Dair Kuşeyri Risalesi, 179.

105 Hasbî, Kitâb-ı Mirkāt-i Merâtib-i İlm-i Ledünnî fî Menâkıb-i Abdülkādir-i Geylânî, 140-141.

106 Hasbî, Kitâb-ı Mirkāt-i Merâtib-i İlm-i Ledünnî fì Menâkıı-i Abdülkādir-i Geylânî, 137-138.

107 Hasbî, Kitâb-ı Mirkāt-i Merâtib-i İlm-i Ledünnî fî Menâkıb-i Abdülkādir-i Geylânî, 145.

108 Hasbî, Kitâb-ı Mirkāt-i Merâtib-i İlm-i Ledünnî fî Menâkıb-i Abdülkādir-i Geylânî, 177.

109 Bk. Râgıb el-İsfahânî, el-Müfredât, 161-162; İbn Manzûr, Lisânü'l-Arab, 15/1290.

110 Bk. Muhammed b. A'lâ b. Ali Hâmid et-Tehânevî el-Fârûkî, Keșşâf-ü ıstılâhâti'l-fünûn ve'l-ulûm, thk. Ali Dahruc (Beyrut: Mektebet-ü Lübnan, 1996), 1/766. 
kendisini cezalandırabilecek olmasından dolayıdır. ${ }^{111}$ Ebû Hafs, havfı, kalbin meşalesi olarak niteleyerek, kalpte bulunan hayır ve şerrin bu meşale ile görüleceğini ifade eder. 112

Recâ ise sözlükte "ümit, emel, ummak, beklenti içinde olmak" gibi anlamlara gelmektedir. ${ }^{113}$ Tasavvuf terminolojisinde, kulun Allah'ın rahmetine güvenerek ümit içinde olmasını ifade etmektedir. ${ }^{114}$ Kuşeyrîyye göre recâ, kalbin gelecekte elde edilebilecek bir isteğe takılıp kalmasıdır. Recâ da tıpkı havf gibi istikbalde vuku bulması umulan bir şey ile ilgilidir. ${ }^{115}$ Vâsıtî, "Korku ve ümit (havf ve recâ), kul itaat halini bırakıp benlik sevdasına düşmesin diye nefsi bağlayan iki yulardır" demiştir.116

Abdülkādir-i Geylânîye göre havf, mahbûbun celâlet ve heybetinden; kahr ve şiddetinden dolayı hissedilen bir hâl olup kalplerde zuhur eden ıztıraptan ibaretdir.117 $\mathrm{Bu}$ açıklamalara göre havf, Allah'ın büyüklüğü karşısında kalbin hissettiği korku halidir.

Abdülkādir-i Geylânî, havfın çeşitlerinden de bahseder. Günahkârdan zuhur eden korkuya havf denir. Âbidînden rehbet, âmilînden haşyet, muhibbînden vecd ve ârifînden zuhur edene ise heybet denir. Günahkârın korkusu cezalandırılmaktan, âbidînin korkusu ibadetlerinin sevabının kaybolmasından ve ölümden, âmilînin korkusu ibadet ve tâatlerindeki gizli şirkten ve ârifînin korkusu ise heybet ve ta'zîmdendir. Ârifinin havfı en şiddetli korkudur ki hiçbir zaman yok olmaz. Havfa ve havfın neticesinde Hakk'ın lütuf ve rahmetine nail olunduğunda, bu duruma mazhar olanın günahlarını cenâb-ı Hak rahmetiyle örter. ${ }^{118}$

Abdülkādir-i Geylânî, kendisine sorulan soru üzerine havf ile recâyı karşılaştırmak suretiyle recâyı açıklamıştır. Onun konuyla ilgili izahı menâkıbnâmede şu şekilde yer almaktadır:

"Evliyâ hakkında rızânın en hakikisi ehlullahın Allah Teâlâ Hazretleri'ne hüsni zanla olan recâsıdır. Recâ ancak havftan oluşur. Zira bir kimse bir şeye vâsıl olmayı recâ eder, o nesnenin kaybolmasından ise havf eder. Allah Teâlâ Hazretleri'ne hüsn-i zan ise ruh ve nefsin temennisi ile kalbin Hakk'a nazarıdır. Havfsız recâ, emîn olmak ve recâsız havf ise ümitsizliktir."119

Abdülkādir-i Geylânî'nin açıklamalarında görüldüğü üzere insan, nail olduğu derece ve mertebeye göre havfı farklı şekilde hisseder ve onu anlamlandırır. Havf ve

\footnotetext{
111 Kuşeyrî, Tasavvuf İlmine Dair Kuşeyri Risalesi, 216.

112 Kuşeyrî, Tasavvuf İlmine Dair Kuşeyri Risalesi, 217.

113 Râgıb el-İ́sfahânî, el-Müfredât, 190.

114 Süleyman Uludağ, "Recâ", Türkiye Diyanet Vakfi İslâm Ansiklopedisi (İstanbul: TDV Yayınları, 2007), 34/502.

115 Kuşeyrî, Tasavvuf İlmine Dair Kuşeyri Risalesi, 222.

116 Kuşeyrî, Tasavvuf İlmine Dair Kușeyri Risalesi, 219.

117 Hasbî, Kitâb-ı Mirkāt-i Merâtib-i İlm-i Ledünnî fî Menâkıb-i Abdülkādir-i Geylânî, 136.

118 Hasbî, Kitâb-ı Mirkāt-i Merâtib-i İlm-i Ledünnî fì Menâkıb-i Abdülkādir-i Geylânî, 136.

119 Hasbî, Kitâb-ı Mirkāt-i Merâtib-i İlm-i Ledünnî fî Menâkıb-i Abdülkādir-i Geylânî, 136-137.
} 
recâ, birbirini tamamlayan ve destekleyen aynı zamanda insan hayatını dengede tutan kavramlardır.

\subsubsection{Fenâ ve Bekâ}

Sözlükte fenâ, "geçici olmak, yok olmak ve ölmek" gibi mânâlar ile karşlanırken"120 bekâ ise fenânın tam zıt bir mânâya sahip olup "kalma, devamlılık, daimî olmak ve evvelki hal üzere kalmak" anlamlarına gelmektedir. ${ }^{121}$ Tasavvufta fenâ ve bekâ kavramları iki ayrı anlamda kullanılmaktadır. Bunların ilki ahlâkî düzlemdedir. Buna göre fenâ, salikin her türlü kötü huy ve alıșkanlıklardan arınmasını, bekâ ise onların yerini alan iyi hasletlerin devamlı hale gelmesini ifade etmektedir. İkinci anlamı ise kulun dünya ile her türlü irtibatını kesip yalnızca rabbi ile meşgul olmasıdır. ${ }^{122}$ Fenâ ve bekâ kavramlarını tarif eden ve kullanan ilk sûfînin Ebû Saîd el-Harrâz (ö. 277/890) olduğu ifade edilmektedir. Ona göre fenâ kulun kendisini görmekten fânî olması, beka ise ilâhî tecellîleri temâşâ etmekle bâkî olmasıdır. Nitekim kulluğu görmek, kulun ibadetleri kendisine nispet etmesi ve onlara güvenmesini doğurur. Bu da rûhî gelişmeyi engelleyen bir durumdur. ${ }^{123}$ Harrâz'a göre kulun her türlü fiilinden kendisini soyutlayıp bunu Allah'a isnat etmesi fenânın ilk adımıdır. ${ }^{124}$

Abdülkādir-i Geylânî’nin belirttiğine göre fenâ, Cenâb-ı Hakk'ın, velisinin sırrına tecelli etmesidir. 0 tecelli ile vücûd telaşlı olur. Yani vücûdun itibarı yok olur. Veli o tecelli ile fânî olur. Velinin o vakitte fenâsı, bekâdır fakat bâkînin icad ve işareti tahtında fâni olduğu için fenâ denmiştir. Her ne kadar onu Hakk'ın telvîh işareti ifnâ eder olduysa da hakikatte onu ifnâ eden Hakk'ın tecellisidir. Velide o tecelli sebebiyle fenâ hali meydana gelir, Hakk'ın işareti tahtında fânî olur. ${ }^{125} \mathrm{Bu}$ açıklamalara göre fenâ, ahlâki düzlemde değil velinin dünya ile irtibatını kesip yalnız rabbi ile meşgul olması anlamında ele alınmıștır. Abdülkādir-i Geylânî̀ye göre fenâ, Allah Teâlâ'nın, velinin sırrına tecellisiyle velinin kendinden geçme hali ve her şeyden fâni olmasıdır.

Abdülkādir-i Geylânî̀ye göre bekâ, kesilme olmayan görüşme ile olur. Bu görüşme ise ancak lemh-ı basar gibi yahut ondan yakın bir hal ve zaman içinde olur. Bekânın aslının alâmeti, fâni bir şeyin kendisiyle birlikte bulunmamasıdır. Zira bekâ ile fenâ iki zıttır, bir arada bulunmazlar. ${ }^{126} \mathrm{Kul}$, beşerî sıfatlardan fâni olursa Allah'a yakınlıkla bekâ bulur.

\footnotetext{
120 Halîl b. Ahmed, Kitâbü'l-Ayn, 3/343; Ebü'l-Hüseyin Ahmed b. Faris b. Zekeriyyâ, Mu'cemü mekâyisi'l-luga, thk. Abdüsselam Muhammed Harun (Beyrut: Dâru'l-Fikr, 1399/1979), 4/453. Halîl b. Ahmed, Kitâbü'l-Ayn, 1/156. Mahmud Esad Erkaya, Kur'an Kaynaklı Tasavvuf Kavramları (Ankara: Otto Yayınları, 2017), 279. Mustafa Kara, "Fenâ", Türkiye Diyanet Vakfı İslâm Ansiklopedisi (İstanbul: TDV Yayınları, 1995), $12 / 333$. Serrâc, el-Lüma', 195.

Hasbî, Kitâb-ı Mirkāt-i Merâtib-i İlm-i Ledünnî fì Menâkıb-i Abdülkādir-i Geylânî, 132. Hasbî, Kitâb-ı Mirkāt-i Merâtib-i İlm-i Ledünnî fî Menâkıb-i Abdülkādir-i Geylânî, 132.
} 


\subsubsection{Tevâcüd, Vecd ve Vücûd}

Her üç kavramda sözlükte "bulma, rastlama, var olma, aşk ve yüksek heyecan duyma" gibi anlamlara gelmektedir. ${ }^{127}$ Sûfîlere göre dinî duygu ve heyecanlar üç şekilde ortaya çıkar. İrade ile vecde gelmeye "tevâcüd", iradesiz vecde gelmeye "vecd", vecdin en mükemmel şekline "vücûd" (bulma) adı verilir. ${ }^{128}$ Tevâcüd yolun başlangıcı, vücûd ise nihayetidir. Bunların ortasında vecd bulunmaktadır. Ebû Ali Dekkâk'a (ö. 405/1015) göre "tevâcüd, kulu kaplayan manevî haller meydana getirir. Vecd, onu manevî heyecanlara gark eder. Vücûd, kulun helak ve yok olmasını gerektirir. Kul bu konuda önce denizi gören, sonra gemiye binen, en nihayet denize açılan kimse gibidir."129

Abdülkādir-i Geylânî'ye göre vücûd; ruhun ve nefsin, zikrin verdiği lezzeti tadarak o zikrin sevinciyle meşgul olmasıdır. Habîb, mâsivâdan alakasını kesmiş olarak Hak'la Hak olmak ve Hak'ta fâni olmak için bâkî kalır. Vücûd, ehl-i tarîk ve erbâb-ı meveddet ıstılahlarında bir aşk ve muhabbet şarabı ayrıca vuslattır ki mevlâ münîr-i kerâmeti üzere velisine su verir, velî onu içtiği anda onda bir hafiflik zuhur eder. $O$ hafiflikle velinin kalbi üns kanadıyla riyâz-ı kudste tayran ederek hakikat denizine düşer ve o halde vâcidi hayret ve baygınlık istilâ eder.130 Abdülkādir-i Geylânî'nin, benzetme ve temsillerden istifade ederek konuyu anlaşılır hale getirdiği görülmektedir.

\subsubsection{Kurb}

Sözlükte "yakın" anlamına gelen kurb kelimesi tasavvuf terimi olarak genellikle karşıtı olan bu'd ile (uzak) birlikte kullanılır. Sûfîlere göre kurb ibadetlere ve tâatlere yakın olmak, bu'd da bunlardan uzak kalmaktır. Kulun Allah'a yakın olması ebedî mutluluğu kazanmasına vesile olan ibadetlere ve iyi davranışlara yakın olması, Allah'tan uzak olması ise ebedî mutsuzluğuna yol açacak kötü işlere yakın olmasıdır.131 Mutasavvıflara göre kulun Allah'a olan yakınlığı, mükâşefe ve müşâhedeye mazhar olması ile gerçekleşir. Aynı şekilde bu'du da mükâşefe ve müşâhededen uzaklaşmasıdır. ${ }^{132}$

Abdülkādir-i Geylânî kurb kavramını, Allah Teâlâ Hazretlerinin, bir kulunu kendine yaklaştırmak için kendisiyle kulu arasındaki mesafe ve menzilleri lütuf ve ihsanıyla kaldırmasından veya kısaltmasından ibarettir ${ }^{133}$ şeklinde tanımlar.

Abdülkādir-i Geylânî, kurbun nasıl kazanıldığı ve etkisi üzerinde de durmuştur. Ona göre Allah Teâlâ'nın kurbiyeti isteniyorsa kalp mâsivâdan

127 Halîl b. Ahmed, Kitâbü'l-ayn, 4/348; İbn Fâris, Mu'cemü mekâyisi'l-luga, 6/86.

128 Semih Ceyhan, "Vecd", Türkiye Diyanet Vakfı İslâm Ansiklopedisi (İstanbul: TDV Yayınları, 2012), $42 / 583$.

Kușeyrî, Tasavvuf İlmine Dair Kușeyri Risalesi, 156.

Hasbî, Kitâb-ı Mirkāt-i Merâtib-i İlm-i Ledünnî fì Menâkıb-i Abdülkādir-i Geylânî, 135-136.

Bk. Süleyman Ateș, "Kurb", Türkiye Diyanet Vakfi İslâm Ansiklopedisi (Ankara: TDV Yayınları, 2002), 26/432-433.

Tehânevî, Keşşâf, 1313.

Hasbî, Kitâb-ı Mirkāt-i Merâtib-i İlm-i Ledünnî fî Menâkıb-i Abdülkādir-i Geylânî, 140. 
uzaklaştırılmalıdır. Böyle yapıldığı takdirde ilâhî tecelli ve feyizler vaki olur. Kalp, gayrullahtan uzaklaştırılarak yalnızca Allah ile meşgul olduğunda ferahlar. Allah'a teveccüh gösterildiğinde ve Allah'tan kurbiyet istediğinde ise kalp müsterih olur. Allah Teâlâ, kulu için hayır istediğinde onu dünyadan korur ve kulun kalbini kendi cihetine cezbeder. ${ }^{134}$

Abdülkādir-i Geylânî'nin açılamalarında görüleceği üzere kurb, rab ile kul arasında oluşan yakınlıktır; aradaki hicâbların azaltılması veya kaldırılmasıdır. 0 ayrıca kurbun oluşması ve neticesinde; kalbin etkisi ve durumuna da dikkat çekmiştir.

\subsection{8. Şevk}

Şevk, sözlükte "istemek, arzulamak, özlemek ve iştiyak" anlamlarına gelmektedir. ${ }^{135}$ Tasavvufta bu özlem daha çok sevgiliye yani Allah'a ulaşma kavuşma iştiyâkl, özlemi olarak ifadesini bulmuştur. ${ }^{136}$ Kuşeyrîye göre, kalbin mahbûba kavuşup görüşmek için heyecanlanmasıdır. ${ }^{137}$ Herevî şevkin gönlün gaip olana doğru esmesi olarak tanımlamaktadır.138

Abdülkādir-i Geylânî’ye göre şevk; ihsan, müşâhede ve rü'yet isteğinden meydana gelen şiddetli arzudur. Visal arttıkça şevklenme de "O' da "daha var mı"139 âyetinde belirtildiği gibi artar. Nefsin; hazlardan ve mâsivâdan alakası kesilmedikçe şevk sıhhatli olmaz. Aşıklar ve müştaklar müşâhede sahibi olsalar da yine de müşâhede arzusunu talep ederler. ${ }^{140} \mathrm{Bu}$ açlklamalarda şevkin müşâhedeyle ilişkisine dikkat çekilmiştir.

\section{Sonuç}

Tefekkür dünyasının zenginliği ve birikimi, kavramların kazandığı anlam alanının genişliğiyle yakından ilgilidir. Kavramlar dinamik bir nitelik taşımaktadır. $\mathrm{Bu}$ nedenle kavramların ruh ve gönül dünyasında kazandığı mananın ifade edilmesi önem arz etmektedir. Dolayısıyla tasavvufî tefekkür sürecinin oluşumu ve dile getirilmesinde kavramların mahiyeti ve bu ıstılahlara yükledikleri anlamları göz önünde bulundurmak önemlidir. Öne çıkan kavramların tespiti ve analizi gerek dönemin kültür özellikleri gerek sûfînin tasavvuf anlayışının daha net bir şekilde anlaşılmasında yol gösterici olacaktır. Bu açıdan bakıldığında sûfî menâkıbnâmeleri de tasavvufî kavram ve konularla ilgili bilgi kaynağı konumundadır.

Kādiriyye tarikatının kendisine nispet edildiği Abdülkādir-i Geylânî (ö. 561/1165-66), kendi döneminde önemli iz bırakması ve kendinden sonra da

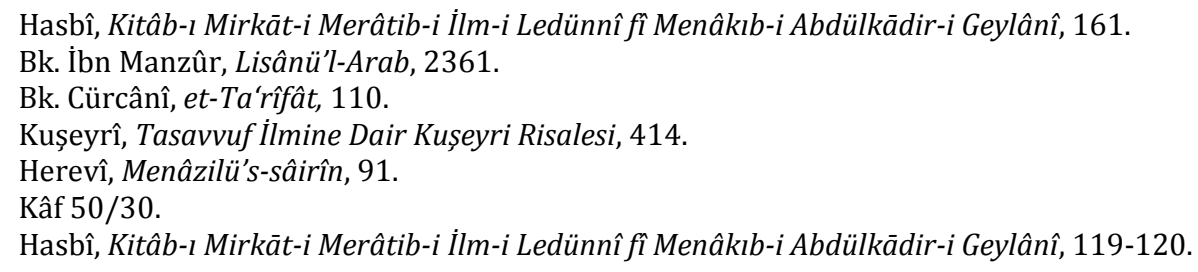


tasavvufî görüş ve anlayışının devam etmesi sebebiyle hakkında birçok menkabe nakledilen bir sûfîdir.

Bu çalışmada Süleyman Hasbî̀ye (ö. 1909) ait olan ve Abdülkādir-i Geylânî’nin menkabelerinden, tasavvufî görüş ve düşüncelerinden bahseden 'Kitâb-ı Mirkāt-i Merâtib-i İlm-i Ledünnî fî Menâkıb-i Abdülkādir-i Geylânî’ adlı menâkıbnâmede yer alan bazı tasavvufî kavram ve konuların Abdülkâdir-i Geylânî'nin gönül dünyasında kazandığı anlam mertebeleri zikri geçen menâkıbnâme özelinde ortaya konulmaya çalışılmıştır.

Bu makalede çalışmaya dahil edilen kavramlar "Tahalluka Dair Kavramlar” ve "Tahakkuka Dair Kavramlar" olmak üzere iki ana başlık altında incelenmiş, Abdülkādir-i Geylânî'nin bu kavram ve konuları hangi çerçevede ele aldığı üzerinde durulmuştur.

Çalışma neticesinde, sohbetleri esnasında ya da kendisine yöneltilen sorular üzerine kavram ve konularla ilgili izahatta bulunan Abdülkādir-i Geylânî'nin birçok tasavvufî kavram ve konuları ele aldığı görülmekle birlikte özellikle "tevekkül, sabır, amelde ihlâs, muhabbet, sıdk" gibi kavram ve konularla ilgili açıklamalara daha fazla yer verdiği müşâhede edilmiştir. Tasavvufta merkezî öneme sahip olan "nefis" konusu, bir başlık altında bütüncül bir şekilde ele alınmamış diğer konular içerisinde işlenmiştir. Bir kavramın izahı esnasında başka kavramlardan da bahsedildiği görülmüştür. Bu durum, kavramların birbiriyle ne kadar ilintili olduğunu da ortaya koymaktadır. Ayrıca kavramların çok katmanlı yapısına da işaret etmektedir. Kavram ve konular ele alınırken konuyu daha anlaşılır kılmak için örnek ve benzetmelerden faydalanıldığı görülmüştür. İzah edilen konuların mümkün mertebe âyet ve hadislerle temellendirildiği de tespit edilmiştir. Dikkati çeken bir husus da yer verilen bu âyet ve hadislerin bir kısmının işârî yorum içermesidir. Bu açıdan bakıldığında da eserin bir başka yönü ortaya çıkmaktadır. Eserde yer alan âyetler göz önünde bulundurulduğunda Hz. Muhammed, Hz. Musa, Hz. İbrahim, Hz. Yusuf gibi peygamberlerden bahseden âyetlerin sıklıkla kullanıldığı görülmüştür. Sûfîler, zâhirî anlamları açısından uygun bulmaları sebebiyle, söz konusu peygamberlerden bahseden bazı âyetlerden, tasavvufî kavram ve/veya konuların temellendirilmesinde ve izahında istifade etmişlerdir.

\section{Kaynakça}

Ateș, Süleyman. "Kurb". Türkiye Diyanet Vakfi İslâm Ansiklopedisi. 26/432-433. Ankara: TDV Yayınları, 2002.

Baklî, Ebû Muhammed Sadrüddîn Rûzbihân b. Ebî Nasr. Meşrebü'l-ervâh. nşr. Nazif M. Hoca. İstanbul: y.y., 1974.

Bursalı Mehmed Tâhir. Osmanlı Müellifleri. haz. Ali Fikri Yavuz - İsmail özen. 3 Cilt. İstanbul: Meral Yayınevi, 1972-1975.

Ceyhan, Semih. "Vecd". Türkiye Diyanet Vakfı İslâm Ansiklopedisi. 42/583-584. İstanbul: TDV Yayınları, 2012. 
Cürcânî, Ebü'l-Hasen Alî b. Muhammed b. Alî es-Seyyid eş-Şerîf el-Hanefî. Mu'cemü't-ta'rîfâtt. thk. Muhammed Sıddîk el-Münşâvî. Kahire: Dâru'l-Fazîlet, ts.

Çağrıcı, Mustafa. "Sıdk". Türkiye Diyanet Vakfı İslâm Ansiklopedisi. 37/98-100. İstanbul: TDV Yayınları, 2009.

Ebû Dâvûd, Süleymân b. el-Eş'as b. İshâk es-Sicistânî el-Ezdî. "Sünen-i Ebû Dâvûd", el-Kütübü'sSitte (Mevsûatü'l-Hadîs eş-Șerîf içerisinde). haz. Sâlih b. Abdulazîz. Arabistan: Dâru'sSelâm, 1421/2000.

Eraydın, Selçuk. Tasavvuf ve Tarikatlar. İstanbul: M.Ü. İlâhiyat Vakfı Yayınları, 7. Basım, 2004.

Erkaya, Mahmud Esad. Kur'an Kaynaklı Tasavvuf Kavramları. Ankara: Otto Yayınları, 2017.

Fîrûzâbâdî, Ebü't-Tâhir Mecdüddin Muhammed b. Yakub b. Muhammed. Besâir zevi't-temyîz fî letâifi'l-Kitâbi'l-Azîz. thk. Ali en-Neccâr. 6 Cilt. Beyrut: Mektebetü'l-İlmiyye, ts.

Geylânî, Abdülkādir. el-Gunye li tâlibî tarîkı'l-Hak. 2 Cilt. Dimaşk: y.y., ts.

Geylânî, Abdülkādir. Cilâü'l-hâtır min kelâmi'ş-şeyh Abdilkādir fi'z-zâhir ve'l-bâtın. İstanbul: İ.Ü. Merkez Kütüphanesi, Arapça, 2325.

Geylânî, Abdülkādir. el-Fethu'r-rabbânî ve'l-feyzu'r-rahmânî. nşr. Muhammed Sâlim el-Bevvab. Beyrut: y.y., ts.

Gürer, Dilaver. Abdülkādir-i Geylânî Hayatı, Eserleri ve Görüşleri. İstanbul: İnsan Yayınları, 9. Basım, 2009.

Halil b. Ahmed, Ebû Abdurrahman. Kitâbü'l-Ayn. thk. A. Hindâvî. 4 Cilt. Beyrut: Dâru'l-Kütübi'lİlmiyye, 2003.

Hasbî, Süleyman. Kitâb-ı Mirkāt-ı Merâtib-i İlm-i Ledünni fî Menâkıb-i Abdülkādir-i Geylânî. İstanbul: Matbaa-i Osmaniye, 1300/1883.

Herevî, Ebû İsmail Abdullah b. Muhammed b. Ali el-Ensârî. Menâzilü's-sâirîn. Beyrut: Dâru'lKütübi'l-İlmiyye, 1408/1988.

Hücvîrî, Ebü'l-Hasen Alî b. Osmân b. Ebî Alî el-Cüllâbî. Keşfü'l-mahcûb (Hakikat Bilgisi). haz. Süleyman Uludağ. İstanbul: Dergâh Yayınları, 3. Basım, 2010.

İbn Fâris, Ebü'l-Hüseyin Ahmed b. Faris b. Zekeriyyâ. Mu'cemü mekâyisi'l-luga. thk. Abdüsselam Muhammed Harun. 6 Cilt. Beyrut: Dâru'l-Fikr, 1399/1979.

İbn Manzûr, Ebu'l-Fadl Cemâluddin Muhammed b. Mükrim b. Ali el-Ensârî. Lisânü'l-Arab. 6 Cilt. Kahire: Dâru'l-Maârif, 1979.

Kara, Mustafa. "Fenâ". Türkiye Diyanet Vakfı İslâm Ansiklopedisi. 12/333-335. İstanbul: TDV Yayınları, 1995.

Kâşânî, Abdürrezzâk. Tasavvuf Sözlügü. çev. Ekrem Demirli. İstanbul: İz Yayınları, 2004.

Kelâbâzî, Ebû Bekr Muhammed b. İbrâhim el-Buhârî. et-Taarrufli-mezhebi ehli't-tasavvuf. haz. Ahmed Şemsüddin. Beyrut: Daru'l-Kütübi'l-İlmiyye, 1413/1993.

Kur'ân-ı Kerîm Meâli. çev. Halil Altuntaş - Muzaffer Şahin. Ankara: Diyanet İşleri Başkanlığı Yayınları, 3. Basım, 2009.

Kuşeyrî, Ebü'l-Kāsım Zeynülislâm Abdülkerîm b. Hevâzin b. Abdilmelik. Tasavvuf İlmine Dair Kuşeyrî Risalesi. haz. Süleyman Uludağ. İstanbul: Dergâh Yayınları, 6. Basım, 2012.

Mansûr Alî Nâsıf el-Hüseynî. et-Tâcu'l-câmiu' li'l-usûl fî ehâdîsi'r-resûl. İstanbul: Mektebetü Pamuk, 1962.

Muhâsibî, Ebû Abdullah Hâris b. Esed. er-Riâye li hukûkillah. Kahire: Şeriketü'l-Kuds, $1429 / 2008$.

Müslim, Ebü'l-Hüseyn Müslim b. el-Haccâc el-Kuşeyrî. "es-Sahîh", el-Kütübü's-Sitte (Mevsûatü'l-Hadîs eș-Șerîf içerisinde). haz. Sâlih b. Abdülazîz. Riyad: Dâru's-Selâm, $1421 / 2000$. 
Râgıb el-İsfahânî, Ebü'l-Kāsım Hüseyn b. Muhammed b. el-Mufaddal. el-Müfredât. Dımıșk: Daru'l-Kalem, 2000.

Serrâc, Ebû Nasr Abdullah b. Alî b. Muhammed et-Tûsî. el-Lüma' fî târîhi't-tasavvufi'l-İslâmî. nşr. Abdülhalîm Mahmud - Tâhâ Abdülkâdir Server. Kahire: y.y., 1960.

Sühreverdî, Ebû Hafs Şihâbüddîn Ömer b. Muhammed b. Abdillâh b. Ammûye el-Kureşî elBekrî. Avârifü'l-maârif. Mısır: Mektebetü'l-Allâmiyye, 1358/1939.

Tehânevî Muhammed b. A'lâ b. Ali Hâmid el-Fârûkî. Keşşâf-ü ıstılâhâti'l-fünûn ve'l-ulûm. thk. Ali Dahruc. 2 Cilt. Beyrut: Mektebet-ü Lübnan, 1996.

Tirmizî, Ebû İsâ Muhammed b. İsâ b. Sevre. "el-Câmi'", el-Kütübü’s-sitte (Mevsûatü'l-hadîsi'şşerîf içerisinde). haz. Sâlih b. Abdülazîz. Riyad: Dâru's-Selâm, 2000.

Uludağ, Süleyman. "Müşâhede". Türkiye Diyanet Vakfi İslâm Ansiklopedisi. 32/152-153. İstanbul: TDV Yayınları, 2006.

Uludağ, Süleyman. "Recâ". Türkiye Diyanet Vakfı İslâm Ansiklopedisi. 34/502. İstanbul: TDV Yayınları, 2007.

Uludağ, Süleyman. Tasavvuf Terimleri Sözlüğü. İstanbul: Kabalcı Yayıncılık, 2012.

Yılmaz, Hasan Kâmil. "Tasavvufla İlgili Sorular ve Cevaplar" (el-Luma', İslâm Tasavvufu içerisinde). İstanbul: Altınoluk Yayınları, 1996. 